Keywords:

- Gravity

- Magnetic

- 3D modelling

- Joint inversion

- Geothermal energy

Received:

12.Desember 2019

Accepted:

25. March 2020

Published online:

18. June 2020

\section{The deep geothermal potential of the radio- genic Løvstakken Granite in western Norway}

\author{
Matthis Frey ${ }^{1} \&$ Jörg Ebbing ${ }^{1}$ \\ ${ }^{1}$ Institut für Geowissenschaften, Christian-Albrechts-Universität zu Kiel, Otto-Hahn-Platz 1, 24118 Kiel. \\ E-mail corresponding author (Matthis Frey): matthisfrey@web.de
}

We developed a first detailed 3D crustal model of the Bergen Region by combining geological information with gravity and magnetic data in order to estimate the geothermal potential of the Løvstakken Granite, which shows a particularly high concentration of radioactive elements. The geometry of the near-surfacehorizonsinthemodelisconsistentwithgeologicalobservationsandinterpretations. The basement structure is, in contrast, associated with greater uncertainties due to the lack of land seismic or deep borehole data. To improve the geological model, we performed stochastic inversions of the gravity and magnetic fields resulting in three plausible models for the Løvstakken Granite. Based on these modelling results, the subsurface temperatures were predicted by numerical simulation and the various influencing factors were investigated, whilst the $516 \mathrm{~m}$-deep Fyllingsdalen borehole provided important thermal constraints. Especially the radiogenic heat production affects the thermal structure of the crust in the Bergen Arcs and we show that the concentration of radioactive elements in the entire basement is on average $50 \%$ smaller than at the surface. The geometry of the Løvstakken Granite also influences the geothermal gradient, but the differences between the three crustal models of $3^{\circ} \mathrm{C} / \mathrm{km}$ are rather moderate. Furthermore, a correction for the paleoclimatic conditions in western Norway is applied which has an effect of up to $7 \pm 4^{\circ} \mathrm{C}$. Lastly, the groundwater influence was determined by creating a coupled fluid flow and heat transport model. Local temperature changes of up to $\pm 5^{\circ} \mathrm{C}$ are found, but there is no significant cooling at the Fyllingsdalen borehole due to groundwater. According to the calculated geothermal gradient in the Bergen Arcs System, the potential for the generation of electricity is relatively low. In comparison, there is an intermediate potential for the extraction of heating energy, in particular in the urban area of Bergen.

\section{Introduction}

Until a few years ago, it was presumed that heat flow and the geothermal gradient are relatively low in the whole of the Norwegian mainland due to its stable tectonic conditions. Consequently, there would be only a small potential for the exploitation of deep geothermal energy (e.g., Sigfússon \& Uihlein, 2015). However, recent investigations, e.g. the Crustal-Onshore-Offshore-Project (COOP) of the Geological Survey of Norway (NGU), revealed that the concentration of radioactive isotopes and thus the radiogenic heat production show large variations (Olesen et al., 2013; Slagstad \& Lauritsen, 2013). In particular, the heat production rates of granitic plutons are up to five times higher than those of the basement gneiss and

\section{(c) Copyright the authors.}

This work is licensed under a

Creative Commons Attribution Frey, M. \& Ebbing, J. 2020: The deep geothermal potential of the radiogenic Løvstakken Granite in western 4.0 International License. 
hence they are a possible target for geothermal exploration. One example is the Løvstakken Granite in the centre of the Bergen Arc System (Pascal \& Rudlang, 2016).

In order to examine the thermal state of the crust in the Bergen Arc System, the Fyllingsdalen borehole was drilled through the upper $516 \mathrm{~m}$ of the Løvstakken Granite in 2011 (Elvebakk \& Storrø, 2013). Unfortunately, the measured thermal gradient was only $16.5^{\circ} \mathrm{C} / \mathrm{km}$ and therefore lower than expected . Elvebakk \& Storrø (2013) suggested that the cooling effect of groundwater flow would be the main reason for this observation. This hypothesis is supported by the highly fractured rocks in the borehole and the abundance of fracture and shear zones in the Bergen Arcs that represent hydraulic pathways for fluids in the subsurface (Fossen \& Rykkelid, 1990; Fossen, 1998; Hermansen, 2019).

Maystrenko et al. (2013) and Maystrenko et al. (2015a) developed 2D crustal and thermal models of the Bergen Arc System to estimate the subsurface temperature distribution. They concluded that a regional groundwater flow from the highland in the east to the northern North Sea in the west significantly affects the thermal gradient. However, the validity of 2D models is limited since lateral heterogeneities are only partly considered. Therefore, we present here a comprehensive 3D model of the Bergen Region by combining all available geological constraints, and geophysical and petrophysical data. The emphasis was on the geological structure of the $L \varnothing v$ stakken Granite since this horizon is probably the main source of radiogenic heat production. Based on the crustal model, we present predictions of the subsurface temperature distribution and investigate the different influencing factors, such as the geological structure, heat production in the basement, paleoclimate conditions, and groundwater flow. Thereafter, we use the models to assess the deep geothermal potential in the Bergen Region.

\section{Geology}

The Bergen Arc System is located around the city of Bergen in western Norway and occupies a total area of about $5000 \mathrm{~km}^{2}$ (Fig. 1). The region comprises several arcuate Caledonian nappes of different origin and metamorphic history, which have been intensively studied since the 19th century (Reusch, 1882; Kolderup \& Kolderup, 1940). In the following, a summary of the tectonic events leading to the formation of the Bergen Arcs is given and the main geological units are briefly described.

\section{Tectonic evolution of the Bergen Arc System}

The present structure of the Bergen Arcs is closely linked to the Caledonian Orogeny, which took place from the late Cambrian to the early Devonian (Gee \& Sturt, 1985; McKerrow et al., 2000; Corfu et al., 2014). The 70 mill.yr lasting convergence of Laurentia, Baltica and Avalonia led to the closure of the lapetus Ocean and subsequently to a continent-continent collision that formed the Himalaya-like Caledonide Orogenic Belt (Gee et al., 2008). During the main collisional event (Scandian phase), a nappe wedge consisting of oceanic and continental domains was thrust eastwards onto the Fennoscandian Shield (Fossen et al., 1998; Fossen \& Dunlap, 2006). This resulted in an extreme thickening of the crust with an increasing thickness in a northwesterly direction accompanied by high- and ultrahighpressure (HP and UHP) conditions between approximately 420 and $400 \mathrm{Ma}$ (Austrheim \& Griffin, 1985). The Scandian phase was followed by an intensive crustal extension along large-scale shear zones like the Bergen Arcs Shear Zone (Fossen, 1992; Wennberg, 1996; Wennberg et al., 1998). This post-orogenic collapse led to a rapid exhumation of the Fennoscandian Shield at around $400 \mathrm{Ma}$. 


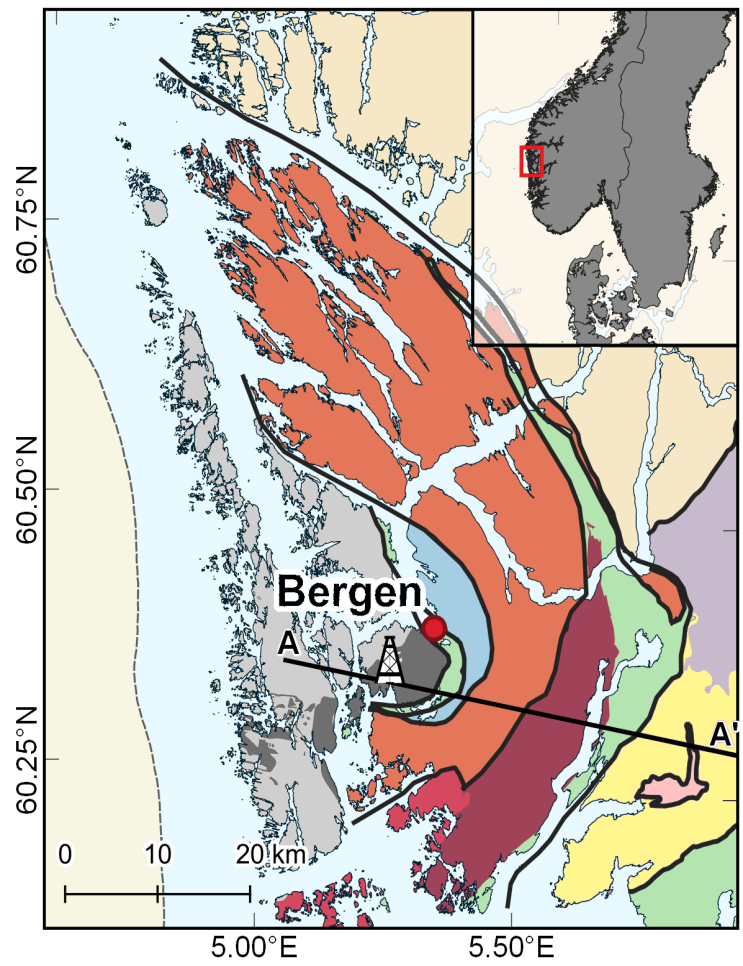

\section{Legend}

Marine Mesozoic Sediments

\section{Caledonian Thrust Sheets}

$\square$ Krossnes Granite

Samnanger Complex/MiBA

Gullfjellet Ophiolite Complex

Lindås Nappe

Blåmanen Nappe

Upper Bergsdalen Nappe

Lower Bergsdalen Nappe

Basement

$\square$ Kikedal Complex

Western Gneiss Region

$\square$ Løvstakken Granite

Øygarden Complex

A Fyllingsdalen Borehole

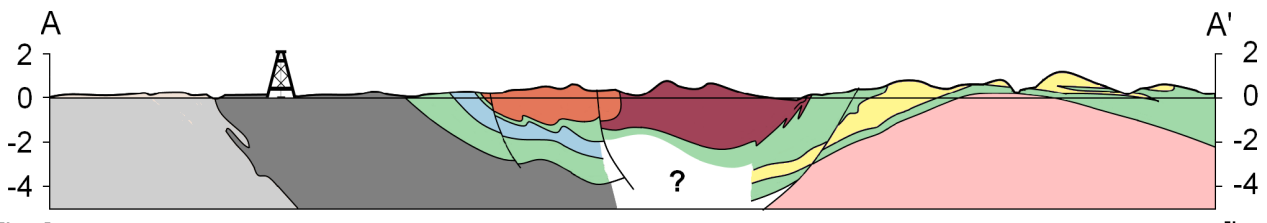

[km]

$[\mathrm{km}]$

Figure 1. Simplified geological map and profile of the Bergen Arc System (modified after Ragnhildstveit \& Helliksen, 1997).

\section{Main tectonic features}

The Basement consists of two main units in the study area, the so-called Western Gneiss Region (WGR) to the northeast and the $\varnothing$ ygarden Complex to the west of the Bergen Arc System. Both formed during several tectonic events in the Precambrian (Sturt et al., 1975). The WGR occupies a total area of about $25,000 \mathrm{~km}^{2}$ between the cities of Bergen and Trondheim and is characterised by uniform, grey gneisses. The $\varnothing$ ygarden Complex is found on the islands of Sotra, Øygarden, Askøy and the Laksevåg peninsula. In general, it consists of heterogeneous, migmatite gneisses and partly mafic rocks (Kolderup \& Kolderup, 1940).

The Løvstakken Granite is an intrusive body within the Øygarden Complex (Fig. 1) which is distinguished by an extremely high content of radioactive elements such as uranium, thorium and potassium (Pascal \& Rudlang, 2016). It consists of granitic gneiss and augen gneiss covering almost the entire Laksevåg peninsula and some parts of Sotra. Structural information suggests that this body is extending underneath the Caledonian nappe structures; however, there are no depth-imaging geophysical data supporting this assumption. Another small basement window with an area of $18 \mathrm{~km}^{2}$ is located to the southeast of the Bergen Arc System. The so-called Kikedal Complex is dominated by red granites that are also enriched in radioactive elements. Whether this complex is a separate body or somehow connected to the WGR or the Løvstakken Granite has not yet been clarified (Maystrenko et al., 2013). 
The Caledonian thrust sheets in the Bergen Arc System can be divided into four main units: The Minor and Major Bergen Arc (MiBA and MaBA), the Lindås Nappe and the Blåmanen Nappe. The MiBA and MaBA are directly overlying the basement. They are part of the Hardangerfjord Nappe (Ragnhildstveit \& Helliksen, 1997) and composed of several complexes of mostly oceanic origin (Fossen \& Dunlap, 2006). The three main units of the MaBA are the Gullfjellet Ophiolite Complex (GOC), the structurally underlying Samnanger Complex which is a tectonic mélange of various geological formations, and the Krossnes Granite (Fig. 1) (Fossen \& Ingdahl, 1987; Dunning \& Pedersen, 1988; Fossen \& Austrheim, 1988; Heskestad et al., 1994). The rocks of the MiBA are similar to those found in the MaBA, but usually much more deformed (Fossen, 1989). Dominant rock types in the MiBA are mica schist, conglomerate, gneiss, quartzite and greenstone that form a complex imbricated structure.

The Lindås Nappe, also known as the Anorthosite Complex, is the largest Caledonian thrust sheet in the Bergen Arc System. It comprises a series of geochemically related rocks of the anorthositemangerite-charnockite-granite suite that are exposed in an area of approximately $1000 \mathrm{~km}^{2}$ (e.g., Middlemost, 1970). This complex is commonly interpreted as a former part of the deeper crust (e.g., Austrheim, 1990). In the western part, eclogites can also be found in zones of strong deformation, which indicates that this nappe was temporarily subducted during the Caledonian Orogeny (Austrheim, 1987; Kühn et al., 2002; Glodny et al., 2008).

The Blåmanen Nappe is located between the MiBA and the Lindås Nappe (Fig. 1). It includes the Ulriken Gneiss Complex (UGC) and the partially overlying Rundemanen formation. The UGC makes up by far the largest part of the nappe and consists of different thrust sheets of migmatite with a Precambrian age (Sturt et al., 1975). The Rundemanen formation contains psammitic metasedimentary rocks preserved in three smaller shear zones (Fossen, 1988; Sylvester \& Janecky, 1988).

To the east and southeast of the Bergen Arcs, there are a number of other Caledonian thrust sheets. The largest one is the Bergsdalen Nappe which extends over an area of approximately $3,000 \mathrm{~km}^{2}$ to the northeast. This tectonic unit consists of detached Precambrian rocks that are located in a décollement zone between the WGR and the thrust sheets of the Bergen Arc System (Fossen, 1993). It can be divided into a Lower and an Upper Bergsdalen Nappe (Fig. 1) that are separated by a thin unit of mica schist.

\section{Data}

Structural constraints for the 3D modelling were mostly given by geological maps and cross-sections, but they only provided information on the uppermost crust in the Bergen Arc System. In order to develop a plausible model for the basement, we additionally used gravity and magnetic data. These are combined with petrophysical analyses of rocks from the surface and the Fyllingsdalen borehole. A description of the different datasets is presented in the following.

\section{Topography, magnetic and gravity data}

Information on the topography was required to construct an accurate model of the shallow geological structures. The data were extracted from the ETOPO1 global relief model (Amante \& Eakins, 2009), which has an original resolution of 1 arc minute. The elevation ranges from about - $200 \mathrm{~m}$ on the Norwegian shelf to more than $1000 \mathrm{~m}$ in the eastern highland (Fig. 2A).

The magnetic data are a compilation of the BESTAS-10 and STAS-13 airborne surveys which were drape-flown with a profile spacing of $250 \mathrm{~m}$ and $1000 \mathrm{~m}$, respectively, and a flight altitude of $60 \mathrm{~m}$ and 

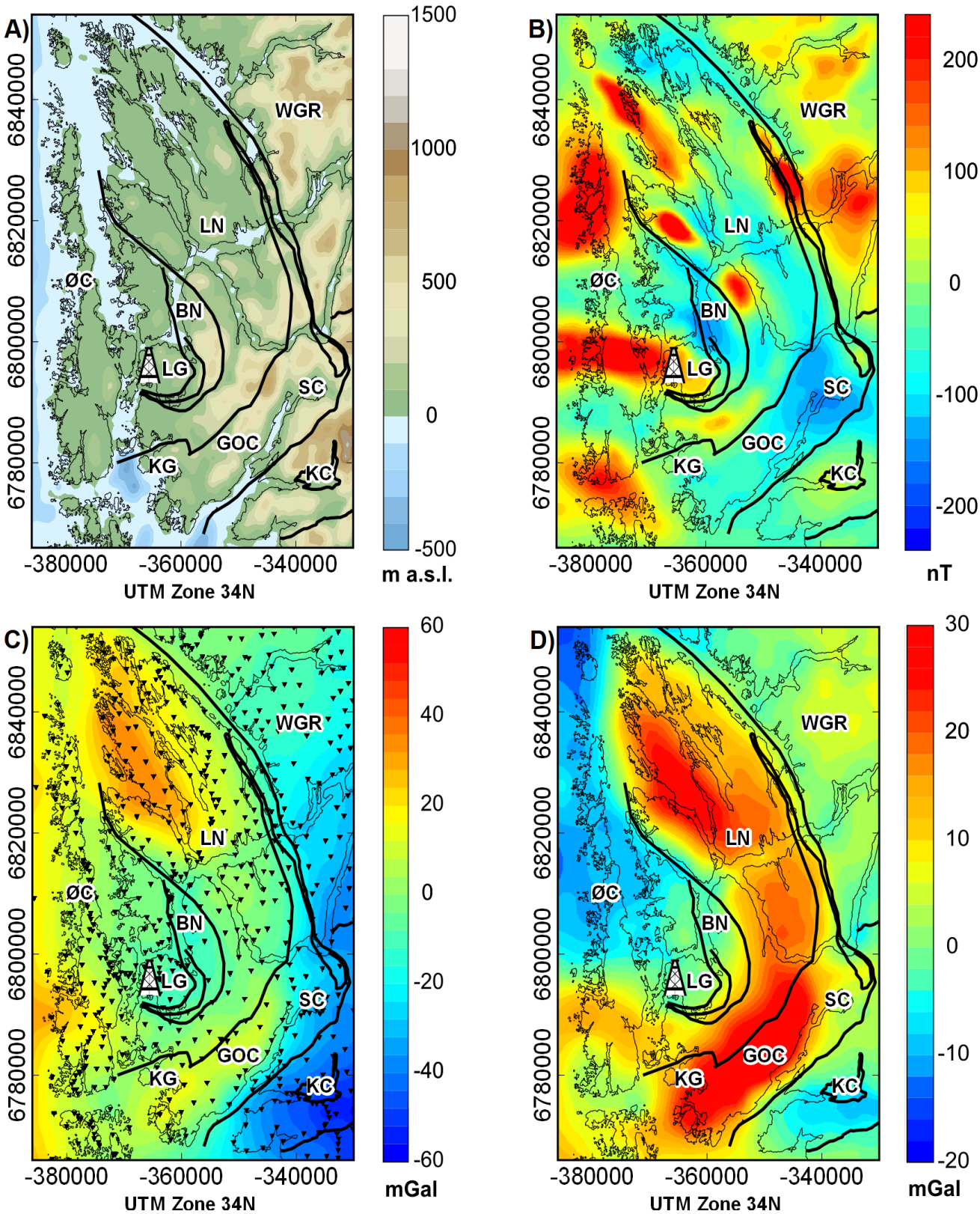

Figure 2. (A) Topography, (B) magnetic anomalies, (C) observed Bouguer anomalies with station locations, and (D) calculated residual Bouguer anomalies in the Bergen Arcs System. BN - Blåmanen Nappe, GOC-Gullfjellet Ophiolite Complex, KC - Kikedal Complex, KG - Krossnes Granite, LG - Løvstakken Granite, LN - Lindås Nappe, ØC - Øygarden Complex, SC - Samnanger Complex, WGR - Western Gneiss Region.

200 m, respectively (Fugro, 2010; EON Geosciences, 2013). The compiled grid has a nominal resolution of $250 \mathrm{~m}$ (Nasuti et al., 2015), but the actual resolution varies across the study area because of the different survey parameters. Compared with the gravity field, the short-wavelength content is much higher in the magnetic anomalies. Because this is difficult to explain with a discretised crustal model, we smoothed the anomaly grid by applying an upward continuation of $1 \mathrm{~km}$ (Fig. 2B). Thereafter, we re-sampled the dataset with a resolution of $1 \mathrm{~km}$.

The magnetic anomalies are mostly in the range of -200 to $+400 \mathrm{nT}$, but also higher values are observed. Large anomaly highs are situated at the Øygarden Complex and WGR; however, there is generally no clear correlation with the geological structures in these areas. One distinct positive anomaly is 
associated with the Løvstakken Granite, but it extends by several kilometres to the west. This could indicate that the granite or fragments of it are partly located underneath the $\varnothing$ ygarden Complex. Apart from the basement, larger highs are associated with the Lindås Nappe. Here, the orientation of the anomalies seems to follow the main strike trend and a correlation between the amplitude and the surface lithology is found (see Fig. 1). The two strongest magnetic lows are associated with the Samnanger complex, the GOC and the Blåmanen Nappe.

For the gravity modelling, we used point data from the NGU which were acquired during various ship and land measurements (Fig. 2C). Bouguer and terrain corrections were carried out by the NGU with a reference density of $2.67 \mathrm{~g} / \mathrm{cm}^{3}$ and with a special focus on the effect of fjords (Olesen et al., 2010). Based on that, we calculated a Bouguer anomaly grid with a cell size of $1 \mathrm{~km}$. Afterwards, we obtained a residual anomaly (Fig. 2D) by subtracting a regional trend from the observed data, because only the structure of the upper crust including the Løvstakken Granite was of interest in this study. The trend was extracted from the large-scale 3D IGMAS model of Maystrenko et al. (2017), whose uncertainties are consequently also affecting our investigations.

The values of the residual Bouguer anomaly range from about - 15 to $+40 \mathrm{mGal}$ in the Bergen Arc System. The largest anomaly highs are associated with the Lindås Nappe and the GOC. Broader highs of up to $10 \mathrm{mGal}$ are found to the southwest on the continental shelf and to the northeast in the WGR and Bergsdalen region. Larger anomaly lows are located in the north of the $\varnothing$ ygarden Complex and in the areas where the Løvstakken Granite and Kikedal Complex crop out.

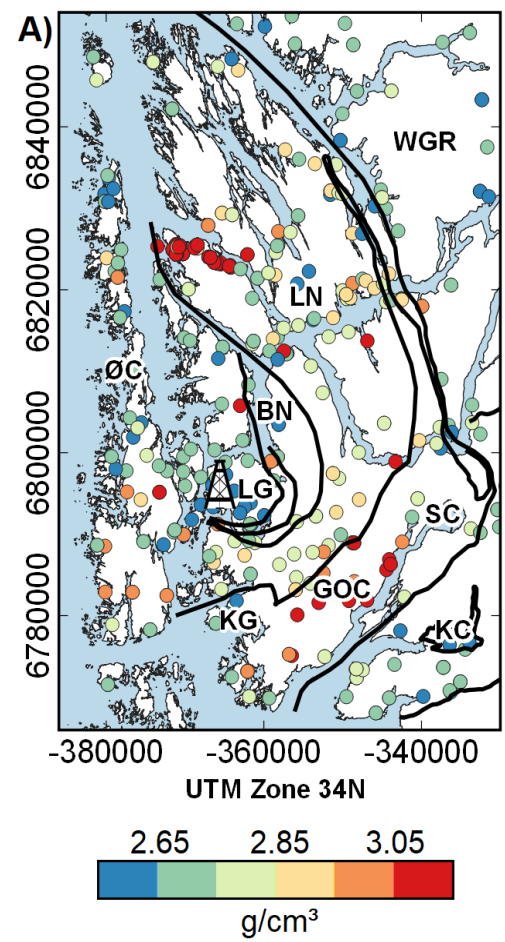

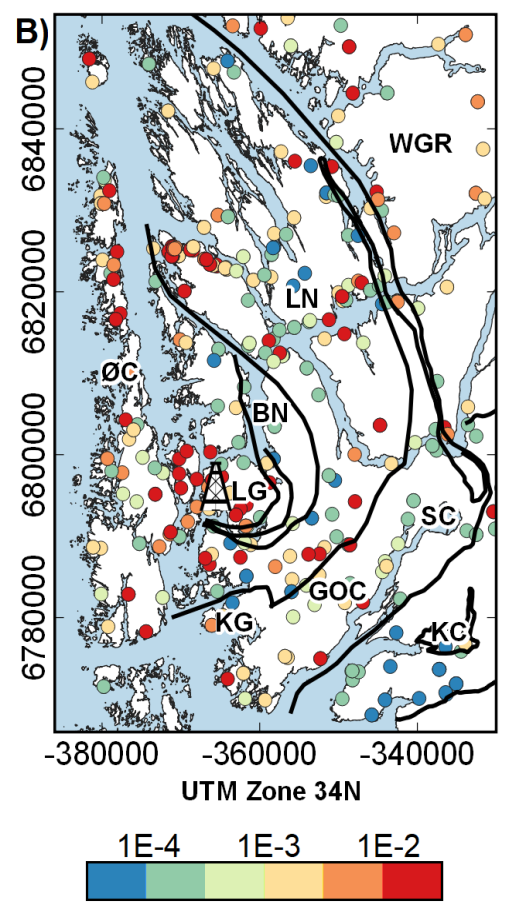

[SI]

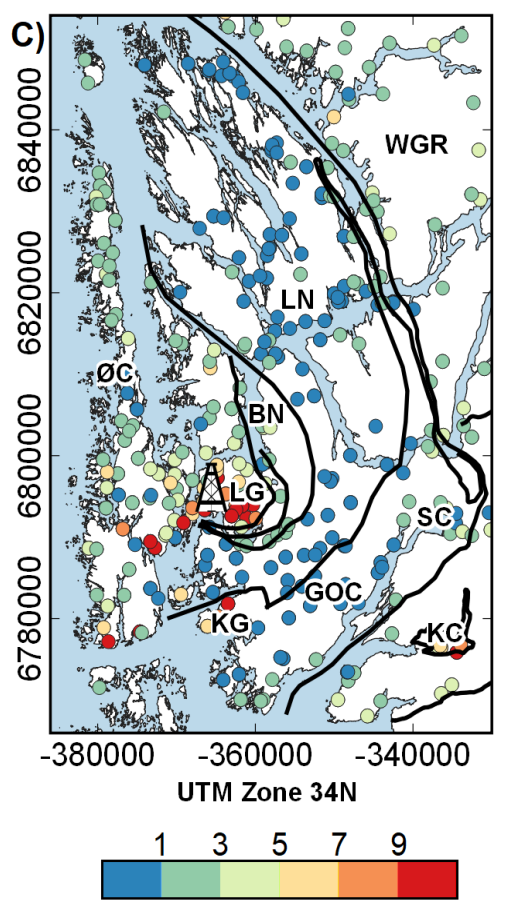

$\mu \mathrm{W} / \mathrm{m}^{3}$

Figure 3. Results of the surface rock analysis in the Bergen Arc System: (A) density, (B) magnetic susceptibility, and (C) radiogenic heat production. BN - Blåmanen Nappe, GOC - Gullfjellet Ophiolite Complex, KC - Kikedal Complex, KG - Krossnes Granite, LG - Løvstakken Granite, LN - Lindås Nappe, $\varnothing C$ - Øygarden Complex, SC - Samnanger Complex, WGR - Western Gneiss Region. 


\section{Petrophysical data}

Detailed knowledge about the spatial distribution of petrophysical properties was required to developed reasonable crustal and thermal models for the Bergen Arc System. The NGU analysed in total 449 surface rock samples in the study area with regard to the density and magnetic susceptibility (Torsvik \& Olesen, 1988; Olesen et al., 1993). The results are illustrated in Fig. 3A, B. The density usually correlates well with the geology. Especially the GOC and the Lindås Nappe consist of high-density rocks and stand out against the other tectonic units. In contrast, the distribution of magnetic properties is much more complex and variable, but nevertheless there are some correlations with the geology. The Lindås Nappe and the basement including the Løvstakken Granite are in general characterised by high susceptibilities. The other Caledonian nappes are on average less magnetic.

For each geological unit, we extracted the density and susceptibility from the dataset to calculate mean values and standard deviations, which were important input parameters for the subsequent modelling and inversion. The obtained petrophysical statistics are summarised in Table 1.

For the temperature prediction, also information on thermal properties was needed. In particular, the radiogenic heat production is significantly controlling the thermal state of the crystalline crust (Turcotte \& Schubert, 2002). For this reason, the NGU determined the trace-element concentrations of about 650 surface rock samples in the Bergen Region mostly by XRF, LA-ICP-MS analysis, and in situ gamma-ray spectrometry (Slagstad \& Lauritsen, 2013; Pascal \& Rudlang, 2016). Based on the estimated concentration of the radioactive isotopes ${ }^{238} \mathrm{U},{ }^{232} \mathrm{Th}$ and ${ }^{40} \mathrm{~K}$, the heat production was calculated using the empirical law of Rybach (1988) shown in Equation 1.

$$
\mathrm{A}=\rho \cdot\left(9.52 C_{U}+2.56 C_{T h}+3.48 C_{K}\right) \cdot 10^{-5}
$$

where $S$ is the heat production, $\rho$ is the rock density, and $C$ the isotope concentration.

Table 1. Summary of the main geological units in the Bergen Arc System with their petrophysical properties.

\begin{tabular}{|c|c|c|c|c|c|c|}
\hline & Horizon & Density $\left[\mathrm{g} / \mathrm{cm}^{3}\right]$ & Susceptibility [SI] & $\begin{array}{l}\text { Heat production } \\
{\left[\mu \mathrm{W} / \mathrm{m}^{3}\right]}\end{array}$ & $\begin{array}{l}\text { Thermal conductivity } \\
\qquad[\mathrm{W} /(\mathrm{mK})]\end{array}$ & $\begin{array}{l}\text { Specific heat } \\
\text { capacity }[\mathrm{J} /(\mathrm{kgK})]\end{array}$ \\
\hline \multirow{7}{*}{$\begin{array}{l}\mathscr{0} \\
\frac{0}{2} \\
\frac{\pi}{2} \\
\frac{0}{0} \\
\frac{0}{\pi} \\
\frac{0}{0} \\
\frac{d}{\sqrt{0}}\end{array}$} & Krossnes Granite & $2.64 \pm 0.02$ & $0.0042 \pm 0.0053$ & $5.4 \pm 2.9$ & 3.0 & $\sim 1000$ \\
\hline & Samnanger Complex & $2.78 \pm 0.09$ & $0.0031 \pm 0.0090$ & $1.9 \pm 1.0$ & 2.8 & $\sim 1000$ \\
\hline & Gullfjellet Ophiolite Complex & $3.01 \pm 0.13$ & $0.0027 \pm 0.0055$ & $0.3 \pm 0.5$ & 2.75 & $\sim 1000$ \\
\hline & Lindås Nappe & $2.82 \pm 0.12$ & $0.0060 \pm 0.0120$ & $0.8 \pm 0.8$ & 2.5 & $\sim 1000$ \\
\hline & Blåmanen Nappe & $2.67 \pm 0.06$ & $0.0005 \pm 0.0003$ & $2.7 \pm 0.8$ & 3.0 & $\sim 1000$ \\
\hline & Upper Bergsdalen Nappe & $2.70 \pm 0.06$ & $0.0003 \pm 0.0006$ & $2.4 \pm 1.3$ & 3.0 & $\sim 1000$ \\
\hline & Lower Bergsdalen Nappe & $2.76 \pm 0.05$ & $0.0021 \pm 0.0073$ & $2.1 \pm 1.0$ & 3.0 & $\sim 1000$ \\
\hline \multirow{4}{*}{ 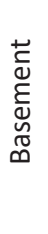 } & Kikedal Complex & $2.65 \pm 0.02$ & $0.0009 \pm 0.0010$ & $5.1 \pm 1.4$ & 3.05 & $\sim 1000$ \\
\hline & Northwestern Gneiss Region & $2.69 \pm 0.09$ & $0.0057 \pm 0.0060$ & $2.9 \pm 1.1$ & 3.0 & 1000 \\
\hline & Løvstakken Granite & $2.66 \pm 0.04$ & $0.0135 \pm 0.0145$ & $8.0 \pm 3.1$ & 3.05 & 1000 \\
\hline & $\varnothing$ ygarden Complex & $2.70 \pm 0.04$ & $0.0114 \pm 0.0258$ & $2.9 \pm 1.7$ & 3.0 & $\sim 1000$ \\
\hline
\end{tabular}


The results are shown in Fig. 3C. Granitic plutons are characterised by the highest heat production rates in the study area. Especially high values in the range of 2 to $13 \mu \mathrm{W} / \mathrm{m}^{3}$ were measured at the $L \varnothing v$ stakken Granite, but radioactive isotopes are also enriched in the Kikedal Complex and the Krossnes Granite. The heat production of basement gneisses in the $\varnothing$ ygarden Complex and WGR is intermediate with an average of $\sim 3 \mu \mathrm{W} / \mathrm{m}^{3}$. The Lindås Nappe, the GOC and the mica schists of the Samnanger complex contain only small amounts of radioactive elements, thus the heat production is low in these areas. In the same way, as for the density and susceptibility, we calculated mean values and standard deviations of the radiogenic heat production for each geological unit (Tab. 1).

Besides, also the specific heat capacity and thermal conductivity affect the conductive heat transport. However, laboratory measurements of these parameters are not available for the Bergen Arcs. The chosen values for these parameters are, therefore, based on the analyses of similar lithologies (Čermak \& Rybach, 1982).

\section{Borehole information}

Following the petrophysical investigations in the Bergen Region, the $516 \mathrm{~m}$ deep Fyllingsdalen borehole was drilled through the Løvstakken Granite in September 2011 (see Fig. 1 for location). It is the only information source on the properties and composition of the granite at greater depth. In March and June 2012, downhole logging of several rock properties was carried out, but the temperature logs were particularly important for the thermal modelling (Elvebakk \& Storrø, 2013). The average thermal gradient was $16.5^{\circ} \mathrm{C} / \mathrm{km}$ and, therefore, lower than expected. Likewise, the rock resistivity was lower than normal values for granites. These observations suggest that cold groundwater might be flowing through fractures in the Løvstakken Granite leading to a decrease of the temperature.

\section{Methods}

A set of methods was used to assess the deep geothermal potential of the Bergen Arc System. The datasets presented above provide a good starting point for 3D modelling of the upper crust. Stochastic inversions were carried out to verify and improve the geological models. The obtained structures of the main tectonic units served then as the basis for the subsurface temperature prediction around the Løvstakken Granite. The applied workflow is illustrated in Fig. 4, and a detailed description of the different methods is given below.

\section{Crustal modelling}

The 3D modelling of the Bergen Arcs System was carried out in several steps. First, a relatively simple model was created using the IGMAS software, which provides an overview of the main geological units (Götze \& Lahmeyer, 1988; Götze, 2013). We defined the model geometry on 14 parallel sections with an E-W orientation. Afterwards, 3D objects, socalled polyhedrals, were generated by automatic triangulation. The software allowed for the forward calculation of the gravity field after assigning the statistical densities from the petrophysical analysis to the individual horizons. The misfit between the calculated and observed gravity anomalies was then iteratively reduced by modifying the geological boundaries and petrophysical properties.

Subsequently, we transferred the 3D IGMAS model to the software GeoModeller (Intrepid Geophysics, 2013). This allowed it to refine the model geometry and to perform inversions as well as 


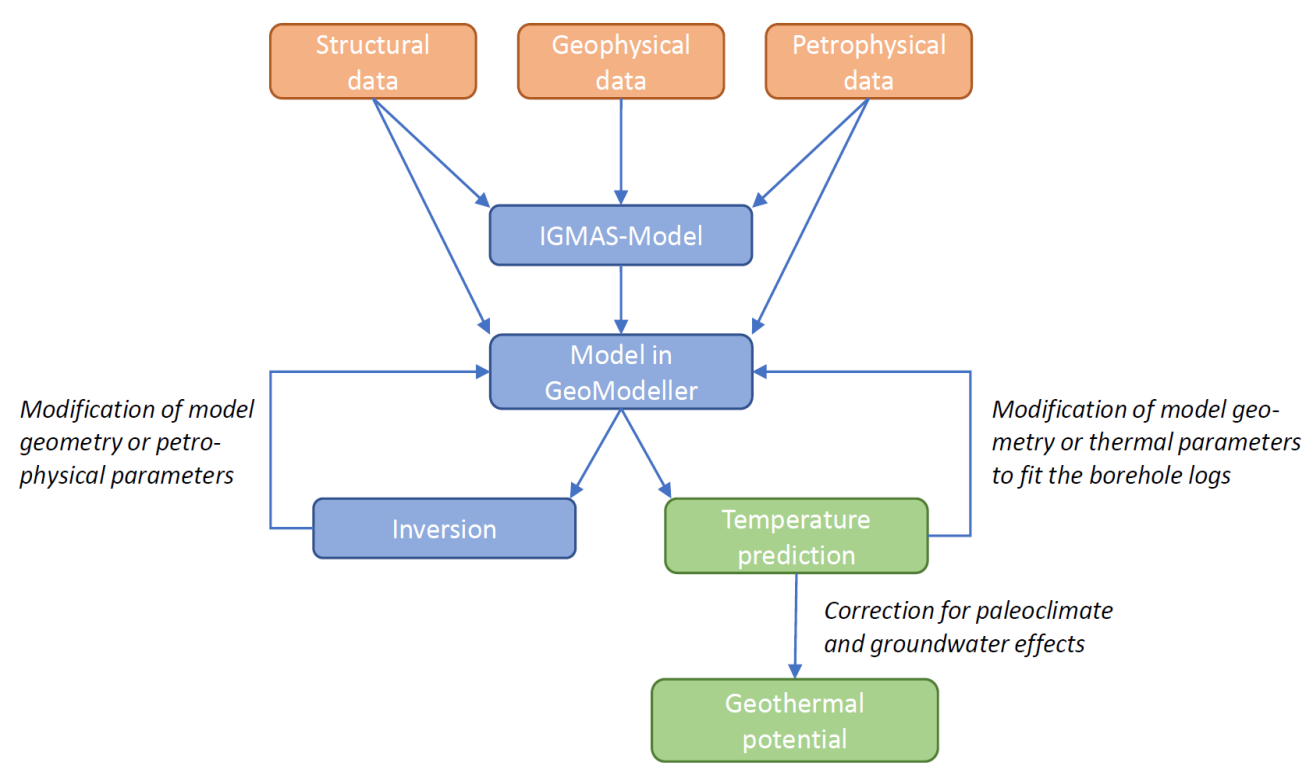

Figure 4. Summary of the different methods used to assess the geothermal potential of the Bergen Arcs System.

thermal calculations. Further geological constraints, especially geological contacts and orientation data (strike and dip), were imported from geological maps and profiles to create a subsurface model which is as realistic as possible. We defined additional contacts on auxiliary sections after computing the model to match the observed surface geology. This introduced a certain degree of subjectivity but was necessary to obtain a consistent geological structure. Moreover, it should be mentioned that the density of geological profiles varies across the Bergen Arcs, hence the uncertainty of the model also changes laterally.

The 3D model has a size of 88 by $56 \mathrm{~km}$, a total depth of $20 \mathrm{~km}$, and the model domain covers the whole Bergen Arc System and some of the adjacent Caledonian nappes. The marine Mesozoic sediments to the west were excluded because of the high density contrast to the crystalline basement and Caledonian nappes.

\section{Inversion}

The so-called Markov-Chain-Monte-Carlo (MCMC) algorithm is implemented in GeoModeller, which is a stochastic inversion method (e.g., Guillen et al., 2004). This approach has the advantages that no complicated mathematical operations, like derivations, have to be performed and that the output is not just one but a collection of possible models. This allows us to estimate the uncertainty of the results.

Initially, the developed crustal model was discretised by converting it into a 3D matrix of cells, called voxels. We used a cell size of $1 \mathrm{~km}$ in most parts of the model. At shallow depths, between - 200 and $1200 \mathrm{~m}$ above sea level, we assigned a smaller cell height of $100 \mathrm{~m}$ to sample the topography adequately. At the beginning of the inversion, density and susceptibility values are randomly chosen for each voxel from the defined probability density functions (mean + standard deviation). Based on this distribution of petrophysical properties, gravity and magnetic anomalies are forward calculated. In the next step, either petrophysical properties or the lithology of every cell is randomly changed by the software. However, the interfaces of the Caledonian nappes were fixed during the inversion to limit the number of variables. The anomalies are later re-calculated and the results are compared with the 
previous model. If the misfit is smaller for the disturbed model, it will be kept. In the other case, it is randomly decided if a model is accepted. This ensures that the inversion explores a variety of possible models and does not get stuck in local minima. This procedure is repeated for 10 million iterations and all accepted models are combined to a summary voxel cube which contains information about the mean density and susceptibility, the standard deviation, and the most probable lithology of a cell.

\section{Thermal modelling}

Finally, we performed the prediction of the subsurface temperatures in the Bergen Arcs based on the crustal modelling and inversion results. The temperatures under pure conductive conditions are forward calculated in GeoModeller by solving Equation 2, a simplified heat transport equation (Gibson et al., 2008).

$$
\nabla \kappa \nabla T=-S /\left(\rho c_{p}\right)
$$

where $\mathrm{T}$ is the temperature, $\mathrm{k}$ the thermal conductivity, $\mathrm{S}$ the heat production, $\rho$ the rock density and $c_{p}$ the heat capacity.

We assumed that there is no heat flow across the 4 vertical sides of the model. A constant temperature was set at the top, which is the annual mean of the study area. According to Tveito et al. (2000), the average temperature was about $6.5^{\circ} \mathrm{C}$ between the years 1961 and 1990 in the Bergen Region. At the bottom, we defined a constant heat flux q from below that can be estimated with Fourier's law of heat conduction shown in Equation 3.

$$
q=-\kappa \nabla T
$$

where $\mathrm{K}$ is the thermal conductivity and $\nabla \mathrm{T}$ the temperature gradient.

For a LAB depth of $110 \mathrm{~km}$ (e.g., Jones et al., 2010), a LAB temperature of $1300^{\circ} \mathrm{C}$, a temperature at the Moho of $600^{\circ} \mathrm{C}$ and an average thermal conductivity of 3 to $4 \mathrm{~J} /(\mathrm{KgK})$ in the mantle (Turcotte \& Schubert, 2002), the heat flux is about $30 \mathrm{~mW} / \mathrm{m}^{2}$.

\section{Paleoclimate correction}

Western Norway was greatly affected by advances and retreats of ice sheets during the past glaciation periods. This was accompanied by changes in the mean surface temperature, which had a significant effect on the crustal thermal gradient (Beardsmore \& Cull, 2001; Slagstad et al., 2009). We performed the paleoclimate correction by applying Equation 4 after Westaway \& Younger (2013).

$$
\delta T(z, t)=\int_{\tau=0}^{t} \Phi(\tau) \exp \left(-z^{2} / 4 \kappa(\tau-t)\right)(t-\tau)^{-3 / 2} d \tau
$$

where $\tau$ is the time step, $\Phi(\tau)$ the surface temperature at time step $\tau$ and $\mathrm{k}$ the thermal diffusivity.

The correction was done for the past 220,000 years and the different paleoclimate scenarios tested are based on the ice-cover model of Olsen (2006). At times when the Bergen Arc System was covered by ice, a surface temperature of $-0.5^{\circ} \mathrm{C}$ is assumed (Fig. $5 \mathrm{~A}$ ), which agrees with observations from Antarctica (Pattyn, 2010). In contrast, the surface temperatures are more uncertain for ice-free conditions. Maystrenko et al. (2015b) suggested an annual mean temperature of $-6^{\circ} \mathrm{C}$, but we investigated also warmer $\left(+8^{\circ} \mathrm{C}\right)$ and colder $\left(-8^{\circ} \mathrm{C}\right)$ scenarios. Fig. $5 \mathrm{~B}$ shows the resulting paleoclimatic effect. 
A) Paleotemperatures in Fyllingsdalen

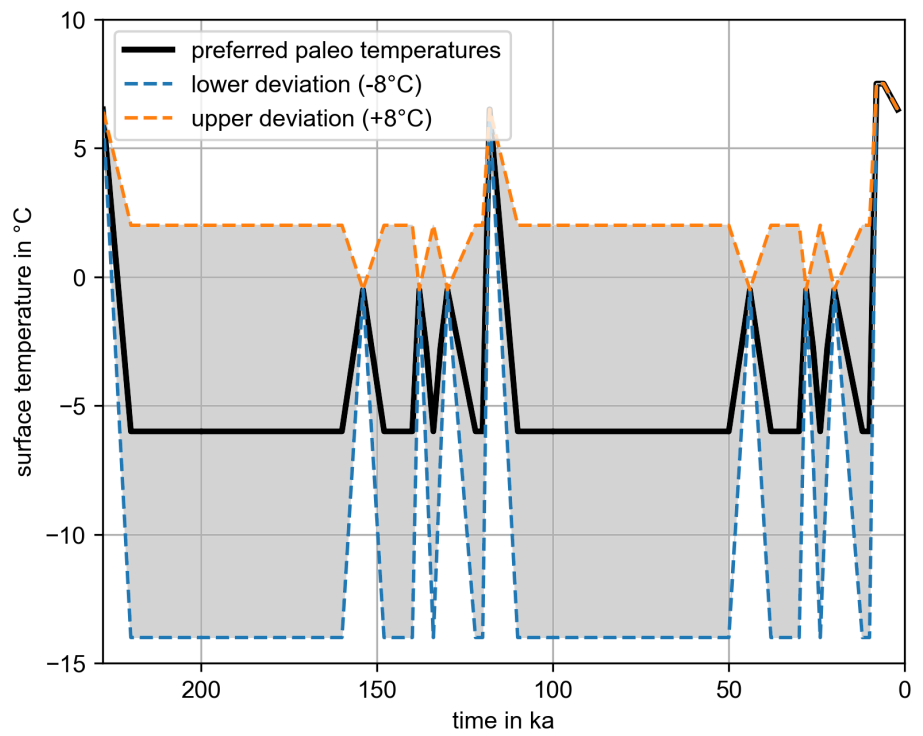

B) Paleoclimate correction

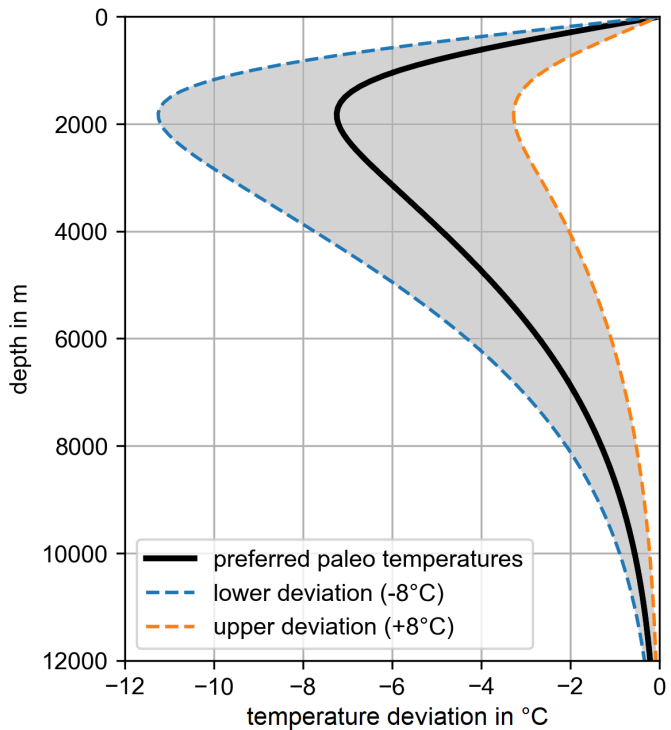

Figure 5. (A) Paleotemperatures at the Fyllingsdalen borehole for the last 220,000 years (Maystrenko et al., 2015b; Olsen, 2006); black line - preferred temperatures, orange line - warm scenario, blue line - cold scenario. (B) Resulting deviation from the normal thermal gradient.

\section{Groundwater modelling}

As stated before, there are several indications of substantial groundwater flow in the Bergen Arcs. It is very likely that this mass flow is contributing quite significantly to the heat transport and thereby affecting the vertical temperature gradient in the study area. In order to quantify the effect, we developed a coupled flow and heat transport model in addition to the pure conductive temperature predictions described above. For this purpose, the software SHEMAT (Clauser, 2003) was used and the modelling was, for simplification, performed in 2D along profile $A-A^{\prime}$ (see Fig. 1 for location). We chose a cell size of $100 \times 100 \mathrm{~m}$ to achieve a reasonable resolution which resulted in a total number of 110,000 cells. A specific lithology was assigned to each cell according to the results of the crustal modelling.

At first, we performed the thermal modelling again for pure conductive heat transport to obtain a reference temperature field. Like before, a constant temperature of $6.5^{\circ} \mathrm{C}$ and a heat flux of $30 \mathrm{~mW} / \mathrm{m}^{2}$ were defined as boundary conditions at the surface and at the base of the model, respectively. The boundary conditions at the eastern and western sides of the model were set to no-flow. Afterwards, the conductive heat transport was coupled with the groundwater flow in the simulation under steady-state conditions and without groundwater sources and sinks. Therefore, Equation 5 was solved in SHEMAT.

$$
-S /\left(\rho c_{p}\right)=\nabla(\kappa \nabla T-u T)
$$

where $\mathrm{S}$ is the heat production, $\rho$ the rock density, $\mathrm{cp}$ the heat capacity, $\mathrm{k}$ the thermal conductivity, $\mathrm{T}$ is the temperature and $u$ the groundwater velocity.

Because comprehensive hydrogeological constraints are not available in the Bergen area, we applied simplified boundary conditions for the groundwater flow. The hydraulic head was set to the elevation of each cell above sea level and kept constant at the surface. Even though this assumption is 
a strong simplification of the reality, it is still a good approximation considering the size of the model. Groundwater flow through the bottom and the sides of the model was not allowed in the simulation. For the permeability of the bedrock, we used the empirical law after Shmonov et al. (2003) shown in Equation 6.

$$
\log k \approx-12.56-3.225 \mathrm{z}^{0.223}
$$

where $\mathrm{k}$ is the permeability in $\mathrm{m}^{2}$ and $\mathrm{z}$ the depth in $\mathrm{km}$.

\section{Crustal models}

\section{Forward modelling}

Initially, we developed a simple IGMAS model which provided an overview of the main geological structures in the study area. This model was then refined using the software GeoModeller. A 3D view and three cross-sections of the modelling result are given in Fig. 6 .

The upper $10 \mathrm{~km}$ of the crust were of particular interest, as the Løvstakken Granite is presumably located in this depth interval. Therefore, we excluded deeper crustal structures, in contrast to the models of Maystrenko et al. (2013). The shallow model geometry is mostly in agreement with the geological profiles, but we adjusted the depth of some interfaces by a few hundred metres in order to fit the gravity anomalies.

The most distinct Bouguer anomalies in the central part of the Bergen Arcs are produced by the GOC and Lindås Nappe, which have a mean density of $3.01 \mathrm{~g} / \mathrm{cm}^{3}$ and $2.82 \mathrm{~g} / \mathrm{cm}^{3}$, respectively. The thickness of

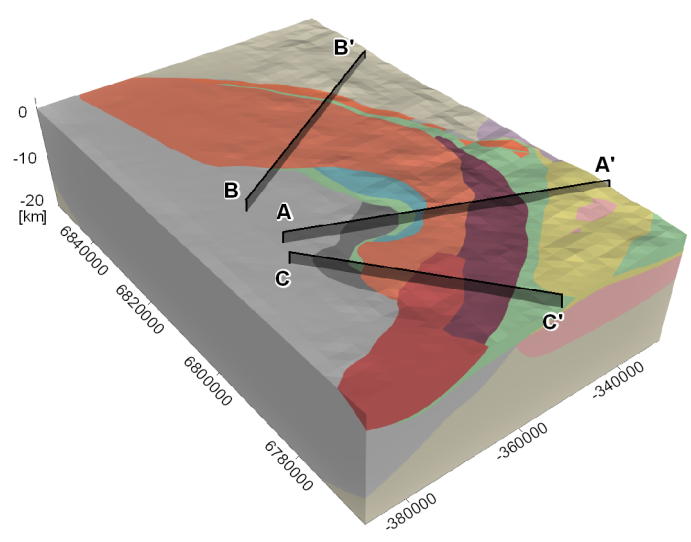

WGS 84 / UTM zone 34N

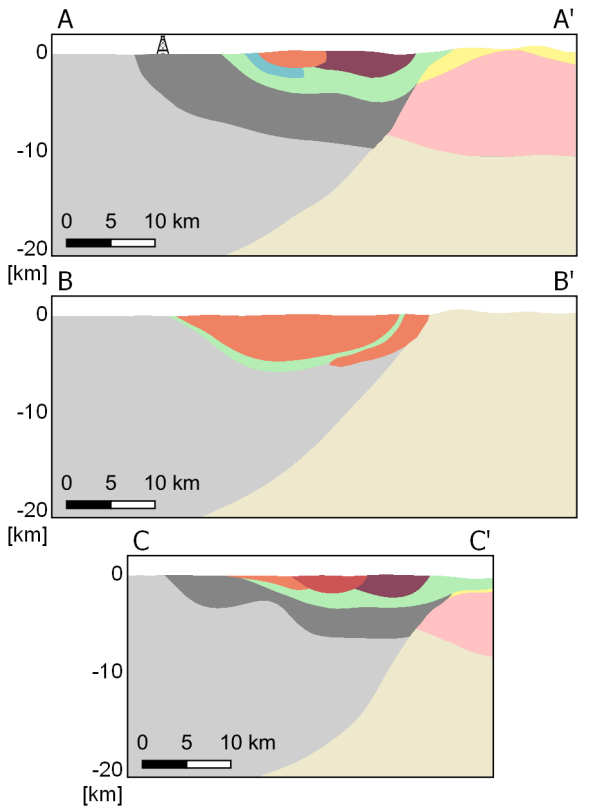

\section{Legend}

Caledonian Thrust Sheets

Krossnes Granite

Samnanger Complex/ MiBA

Gullfjellet Ophiolite Complex

Lindås Nappe

\section{Basement}

Blåmanen Nappe Upper Bergsdalen Nappe Lower Bergsdalen Nappe

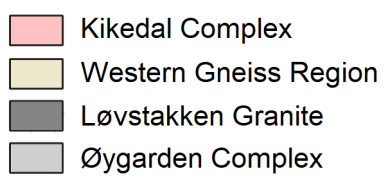

Figure 6. Results of the crustal modelling in GeoModeller. Left: 3D overview of the model, right: three cross-sections through the model. 
these two units reaches up to $5 \mathrm{~km}$ in our model, but there are lateral variations. Almost in the entire Bergen Arc System, an approximately $1 \mathrm{~km}$ thick layer of mica schist forms the base of the Caledonian nappes which leads altogether to a maximum thickness of the thrust sheets of about $6 \mathrm{~km}$.

We divided the basement into the four units; Øygarden Complex, Western Gneiss, Løvstakken Granite and Kikedal Complex. However, it should be noted that the locations and depths of the modelled interfaces are associated with great uncertainties because there are no geophysical data that image the subsurface structures in the Bergen Region. The contact between the $\varnothing$ ygarden Complex and the WGR was modelled according to the interpretation of Fossen (1992). In contrast, the separation of the Løvstakken Granite and the Kikedal Complex was based mainly on the different magnetic properties and the observed anomalies (see Fig. 2). In our model, these two bodies form a continuous granite horizon underneath the Caledonian nappes with a maximum depth of about $10 \mathrm{~km}$.

For this model, there is broad consistency between the forward calculated and observed Bouguer anomaly with a standard deviation of about $7 \mathrm{mGal}$. All major gravity anomalies can, therefore, be explained by known geological bodies. Larger deviations of up to $15 \mathrm{mGal}$ occur mainly at the $\varnothing$ ygarden Complex, but also at the Krossnes Granite, Gullfjellet Ophiolite and southern part of the Lindås Nappe. In comparison, the misfit of the modelled magnetic anomalies is much larger with a standard deviation of $90 \mathrm{nT}$. Especially the short-wavelength content and the high amplitudes are not reproduced. Hence, the main tectonic units are characterised by strong internal variations of the susceptibility, which we did not consider in the forward modelling.

\section{Inversion results}

The developed geological model served as a starting point for the subsequent MCMC inversion. Thereby, the misfit between the calculated and observed anomalies was minimised by stochastic variation of the petrophysical parameters and the lithology. The probability density functions of the density and magnetic susceptibility used during the inversion are based on the statistical values in Table 1; however, the standard deviations are in some cases very high. They were, therefore, adjusted because they would lead to unrealistic values of the petrophysical properties. For the density, we used a standard deviation of $0.025 \mathrm{~g} / \mathrm{m}^{3}$ and $0.05 \mathrm{~g} / \mathrm{cm}^{3}$ in the basement and the Caledonian nappes, respectively. For the susceptibility, we defined a standard deviation of 0.005 [SI] for all horizons.

\section{Model A}

At first, we only used the gravity data in the inversion. The result is referred to as Model A in the following. Fig. 7 shows the initial and final density distribution as well as the most probable lithology after inversion. The Caledonian nappes can be clearly distinguished from the basement in our density model and especially the Lindås Nappe and the GOC are characterised by high densities. Moreover, there is also a significant contrast between the Løvstakken Granite and the underlying gneiss. However, a separation of the Løvstakken Granite and the Kikedal Complex is not possible based on the inverted densities. At the surface, strong lateral variations of the density occur, which explain the shortwavelength part of the gravity anomalies. In contrast, the density is almost homogeneously distributed in the lower $10 \mathrm{~km}$ of the model.

The most significant changes in lithology compared to the starting model can be observed at the Løvstakken Granite. It is not a continuous horizon anymore but split into two distinct parts below the Caledonian nappes. Besides, the thickness of the granite is increased by up to $3 \mathrm{~km}$ near the Fyllingsdalen borehole in the western part of the model. The other basement units show, in contrast, only minor changes after the inversion. 


\section{Model A}
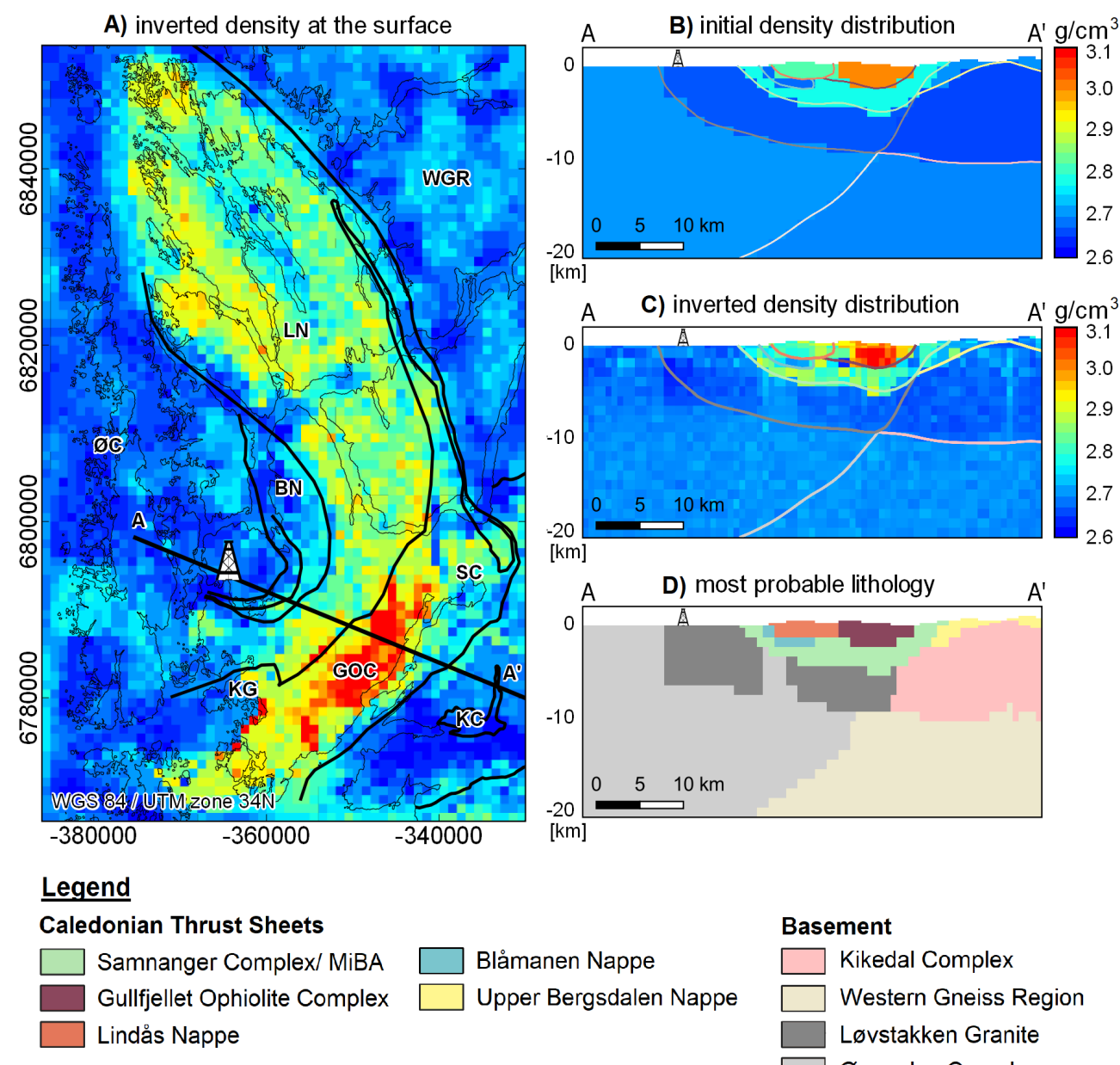

$[\mathrm{km}]$
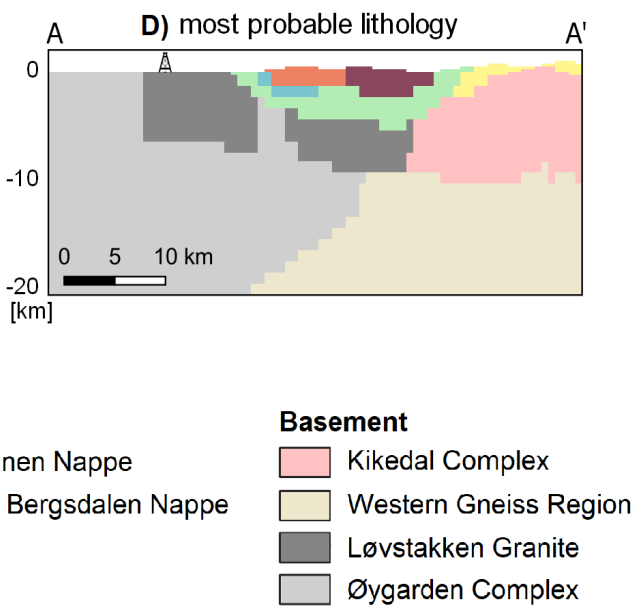

Figure 7. Results of the gravity inversion: (A) inverted density distribution at the surface, (B) cross-section through the initial density model, (C) cross-section through inverted density model, and (D) cross-section through the most probable lithology model. BN-Blåmanen Nappe, GOC-Gullfiellet Ophiolite Complex, KC-Kikedal Complex, KG-Krossnes Granite, LG - Løvstakken Granite, LN - Lindås Nappe, ØC - Øygarden Complex, SC - Samnanger Complex, WGR Western Gneiss Region.

\section{Model B}

Since the initial geological model is already partly based on the Bouguer anomalies, the insights gained from a simple gravity inversion are limited. Therefore, we introduced additional constraints by considering also the magnetic data. Model B, shown in Fig. $8 \mathrm{~A}-\mathrm{C}$, is the result of the joint inversion of both datasets using the same parameters and starting model as before. The inverted density distribution is similar to Model A, but the variability of the parameter is higher (Fig. 8A).

There is in general no clear correlation between the inverted susceptibility distribution and the density (Fig. 8B). The Caledonian nappes are characterised by mostly low susceptibilities. In comparison, the parameter is very heterogeneous in the basement and there are zones of higher and lower susceptibility which agree with the observations at the surface (see Figs. 2B \& 3B). Apart from that, the Løvstakken Granite has on average a higher susceptibility than the Kikidal Complex; hence, these two geological bodies can be distinguished based on their magnetic properties. 
Model B

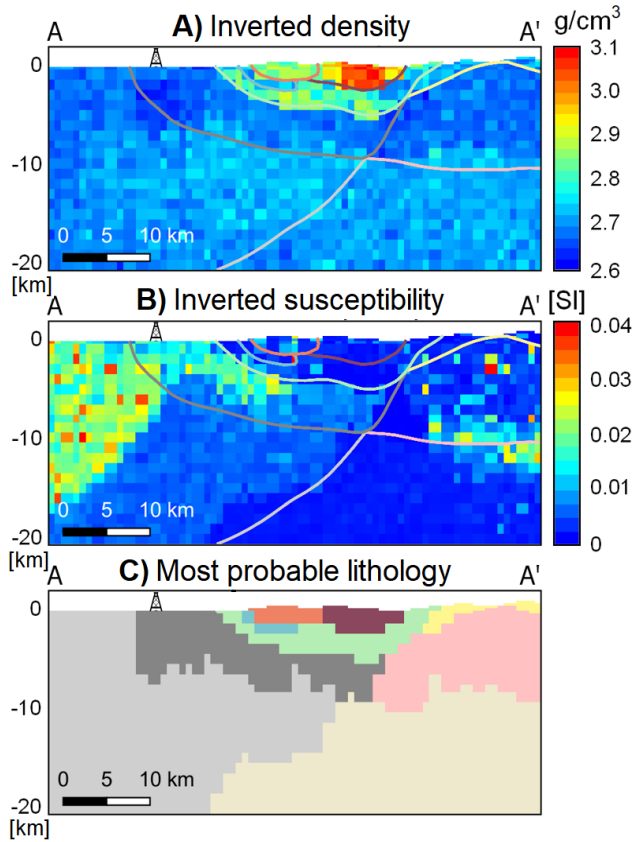

Model C
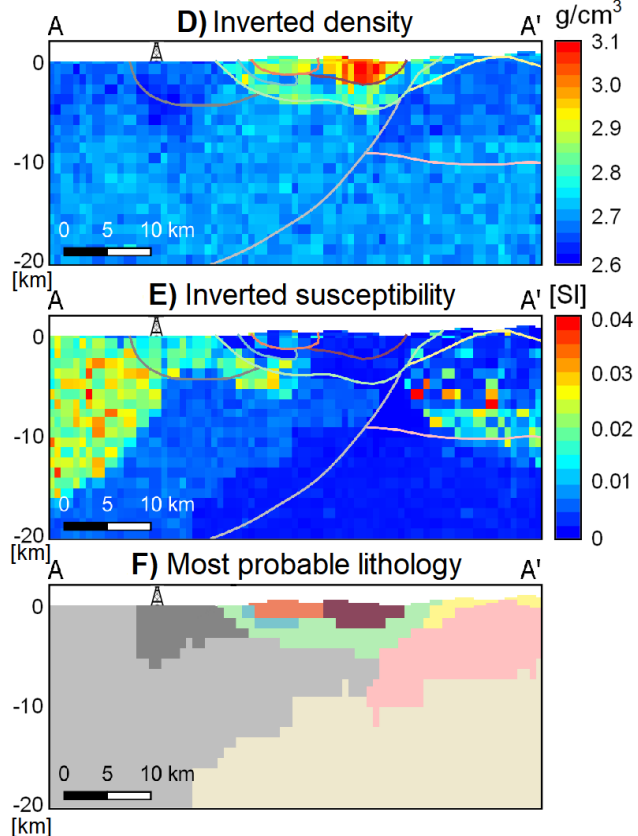

\section{Legend}
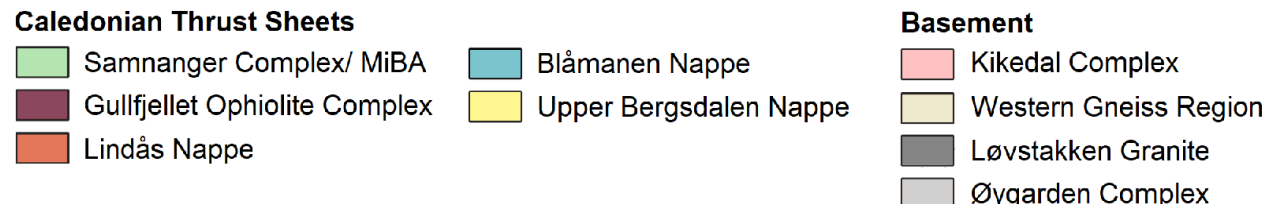

Figure 8. Results of the joint inversion of gravity and magnetic data using two different starting models. (A \& D) cross-sections through the inverted density model, ( $B$ \& E) cross-sections through the inverted susceptibility model, (C \& F) cross-sections through the most probable lithology model.

Fig. $8 \mathrm{C}$ shows the most probable lithology model found by the inversion. In comparison to the starting model, the base of the Løvstakken Granite is now much more undulating, but it is still a continuous horizon. As in Model A, the thickness of the granite is highest at the Fyllingsdalen borehole and decreases underneath the Caledonian nappes. Besides, the interfaces of the Øygarden Complex, Western Gneiss and Kikedal Complex were shifted by several hundred metres.

\section{Model C}

The outcome of the MCMC inversions depends furthermore on the starting model. For this reason, we tested an alternative to the model shown in Fig. 6, in which the Løvstakken Granite has a considerably smaller volume and is only extending over a few kilometres underneath the Caledonian nappes. A joint inversion of gravity and magnetic data was again performed and the resulting Model $\mathrm{C}$ is presented in Fig. 8D-F. The inverted density and susceptibility distributions are very similar to Model B. Onemajor difference, howev-er, isthat the density of the basementisconsiderablysmallerdirectly below the Caledonian nappes. Again, the thickness of the Løvstakken Granite is greatest in the area of the Fyllingsdalen borehole and decreases eastwards. The changes of the $\varnothing$ ygarden Complex, Western Gneiss and Kikedal Complex are in the same range as in Model B. 
Despite the differences in the basement geometry and property distribution between the Models A, $B$ and $C$, a similarly good fit of the gravity and magnetic anomalies was achieved in the inversions. The final standard deviation is in each case about $0.5 \mathrm{mGal}$ for the gravity and $16 \mathrm{nT}$ for the magnetic field, which is significantly better than the result of the forward modelling. Consequently, all three models can be considered as plausible.

\section{Thermal models}

We used the three alternative geological models presented above to estimate the subsurface temperatures in the Bergen Arc System. Thereby, we examined the different influencing factors such as the radiogenic heat production, the structure of the Løvstakken Granite, and the effect of the groundwater. Afterwards, an estimate of the deep geothermal potential was possible based on the results.

\section{Quantification of the influencing factors}

The radiogenic heat production significantly affects the thermal state of the continental crust. In the case of the Bergen Arcs, information on this parameter is available from the surface and the relatively shallow Fyllingsdalen borehole, but not from greater depths. However, as the concentration of radioactive elements tends to decrease with depth in the crust, we investigated three different heat production scenarios (Table 2 ).

Fig. 9A shows a comparison of the predicted temperatures for the three parameter sets and the temperature logs from the Fyllingsdalen borehole for Model B. We carried out a correction of the results regarding the paleoclimatic effects as described above (see Fig. 5B). The closest match with the observations was found for the relatively low heat production. For the other two cases, the error is about $3 \pm 2^{\circ} \mathrm{C}$ and $7 \pm 2^{\circ} \mathrm{C}$, respectively, at the base of the borehole.

Besides the subsurface temperatures, also the vertical heat flux was calculated for the three cases. Values of more than $100 \mathrm{~mW} / \mathrm{m}^{2}$ were determined at the Fyllingsdalen borehole for the high and intermediate heat production. The relatively low heat production leads, by contrast, to a heat flux of about $75 \mathrm{~mW} / \mathrm{m}^{2}$ which is in agreement with the findings of Maystrenko et al. (2015b). Hence, it can be concluded that the concentration of radioactive isotopes in the basement is on average $\sim 50 \%$ smaller than at the surface.

Table 2. Three different parameters sets of the radiogenic heat production used for the thermal modelling.

\begin{tabular}{|c|c|c|c|c|}
\hline & \multirow[b]{2}{*}{ Horizon } & \multicolumn{3}{|c|}{ Radiogenic heat production $\left[\mu \mathrm{W} / \mathrm{m}^{3}\right]$} \\
\hline & & $\begin{array}{l}\text { Case I } \\
\text { high heat prod. }\end{array}$ & $\begin{array}{l}\text { Case II } \\
\text { interm. heat prod. }\end{array}$ & $\begin{array}{c}\text { Case III } \\
\text { low heat prod. }\end{array}$ \\
\hline \multirow{4}{*}{ 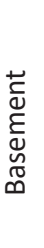 } & Kikedal Complex & 5.1 & 5.1 & 2.5 \\
\hline & Northwestern Gneiss Region & 2.9 & 1.5 & 1.5 \\
\hline & Løvstakken Granite & 8.0 & 8.0 & 4.0 \\
\hline & $\varnothing$ ygarden Complex & 2.9 & 1.5 & 1.5 \\
\hline
\end{tabular}


A) Effect of the heat production

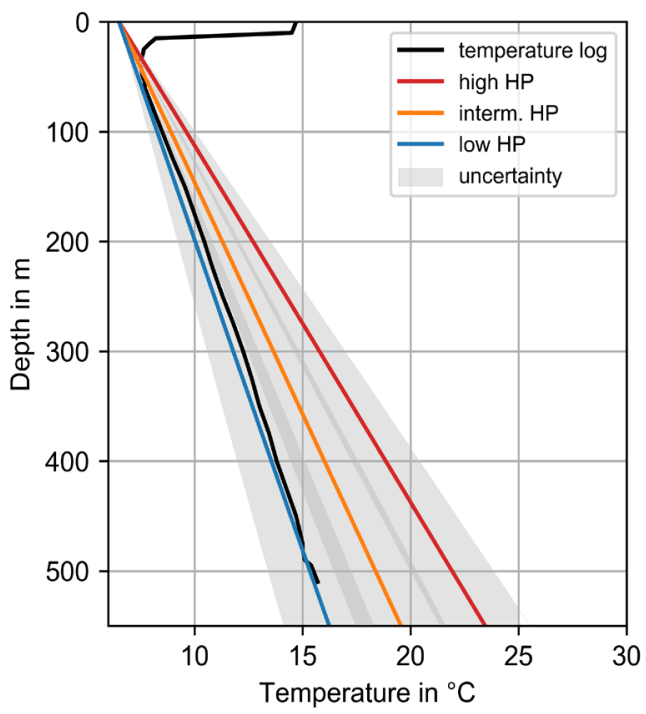

B) Effect of the geological structure

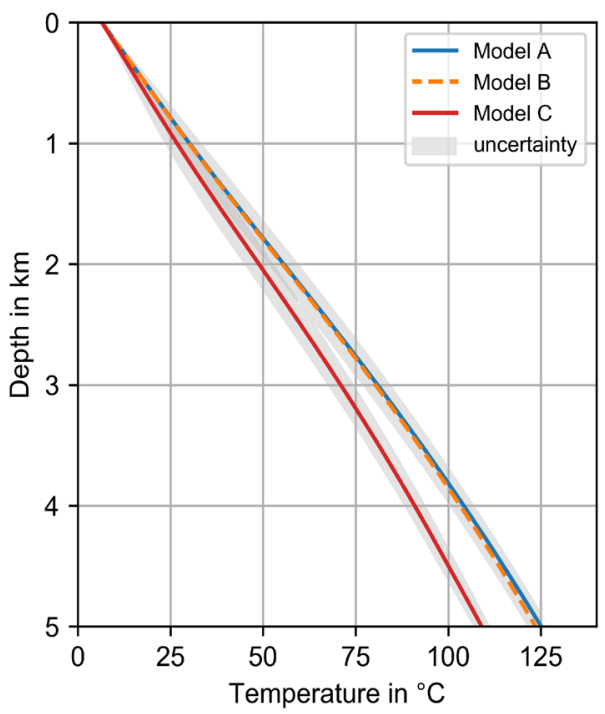

Figure 9. Results of the temperature prediction: (A) comparison of different heat production rates with the temperature logs in the Fyllingsdalen borehole, (B) Comparison of the predicted temperatures for the three plausible 3D models of the Bergen Arc System (see Fig. 7). The grey area illustrates the uncertainty of the paleoclimate correction.

We performed the temperature prediction also for the three plausible crustal models derived by the stochastic inversion (see Figs. 7 \& 8) using the relatively low radiogenic heat production. The resulting thermal gradients range from about 22 to $25^{\circ} \mathrm{C} / \mathrm{km}$ at the Fyllingsdalen borehole location (Fig. 9B). The differences between the calculated temperatures for the Models A and B are very small especially in the upper $2 \mathrm{~km}$, but even at $5 \mathrm{~km}$ depth the differences are still smaller than the uncertainty of the paleoclimate correction. The predicted temperatures for Model $\mathrm{C}$ are, by comparison, significantly lower. The geothermal gradient is in this case about $3^{\circ} \mathrm{C} / \mathrm{km}$ smaller.

Finally, we developed a coupled 2D groundwater and heat transport model to estimate the effect of fluid flow on the geothermal gradient in the Bergen Arcs. The calculated groundwater velocities show a clear correlation with the topography (Fig. 10A). The highest velocities are observed especially in the eastern part of the study area because of the steep terrain. Moreover, the fluid flow is generally limited to the upper 2 to $3 \mathrm{~km}$ of the crust and a regional groundwater flow from the highlands in the east towards the northern North Sea, as suggested by Maystrenko et al. (2015a), was not found. Instead, the water seems to follow the hydraulic gradient from the topographic highs to the next fjord or valley.

The coupling of groundwater flow and conductive heat transport resulted in a change of the modelled subsurface temperatures in the range of $\pm 5^{\circ} \mathrm{C}$ which is shown in Fig. 10B. A temperature decrease was determined at the topographic highs, for example at the Lindås Nappe, the GOC, or in the very east of the model domain. In contrast, the simulated temperatures are higher compared to the reference value in the lower areas. The changes at the Fyllingsdalen borehole are in the range of $\pm 1^{\circ} \mathrm{C}$; therefore, the groundwater flow has only a minor effect on the geothermal gradient at the drill site according to our simulation. 

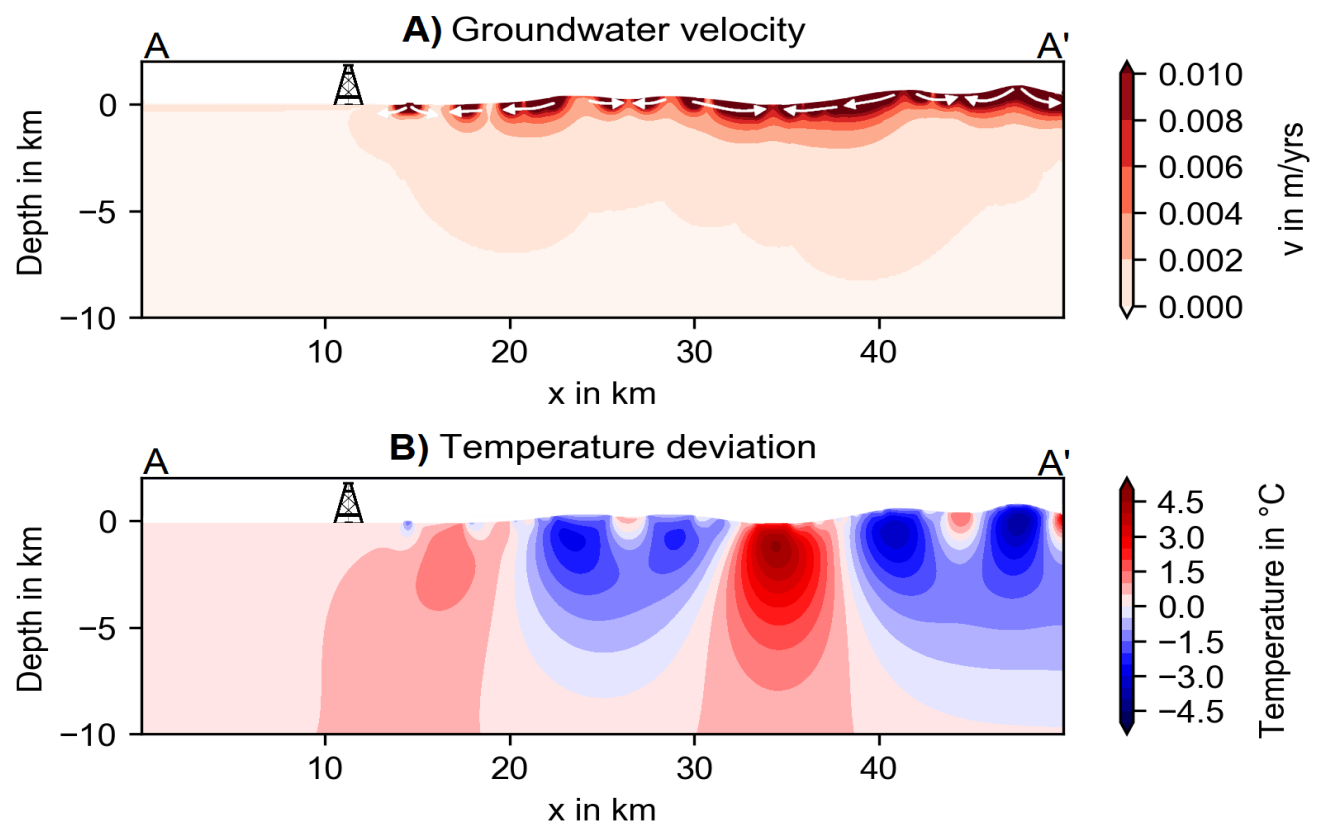

Figure 10. Results of the coupled 2D groundwater and heat transport modelling: (A) simulated groundwater velocities and general direction of the fluid flow, $(B)$ resulting deviation from the reference temperature field due to groundwater flow.

\section{Estimate of the geothermal potential}

The main tectonic units in the Bergen Arcs are characterised by a relatively low permeability and the subsurface can, therefore, be classified as a petrothermal system (e.g., Bauer et al., 2014). Hence, the assessment of the deep geothermal potential is in particular based on the temperature distribution in the upper crust. For the extraction of hot water, which could be fed into the district heating network, a minimum temperature of $60^{\circ} \mathrm{C}$ should be reached. In comparison, the technical limit for generating electricity is about $100^{\circ} \mathrm{C}$. These two isotherms are shown in Fig. $11 \mathrm{~A}, \mathrm{~B}$ for Model $\mathrm{B}$ of the $L \varnothing v$ stakken Granite and a low radiogenic heat production in the basement. The depth of the $60^{\circ} \mathrm{C}$ isotherm ranges from 2 to $3 \mathrm{~km}$ below sea level and is especially low in the centre of the Caledonian nappes. This observation can be explained by the comparatively low thermal conductivity of the thrust sheets, which act as a 'thermal blanket'. In these areas, there is consequently an intermediate potential for generating heating energy. A similar pattern is also found for the $100^{\circ} \mathrm{C}$ isotherm, but the depth is in a range of 4 to $5.5 \mathrm{~km}$. For this reason, a geothermal drilling for the production of electricity would most likely not be economical.

The extraction of hot water for heating purposes is particularly reasonable in areas with locally high thermal gradients. Fig. $11 \mathrm{C}$ shows the distribution of the vertical temperature gradient in the Bergen Arc System. Comparatively high values between 25 and $30^{\circ} \mathrm{C} / \mathrm{km}$ occur especially within the Caledonian nappes in the topographically lower regions. This includes the urban area of Bergen, so that any potential energy production can be performed close to the consumers. 

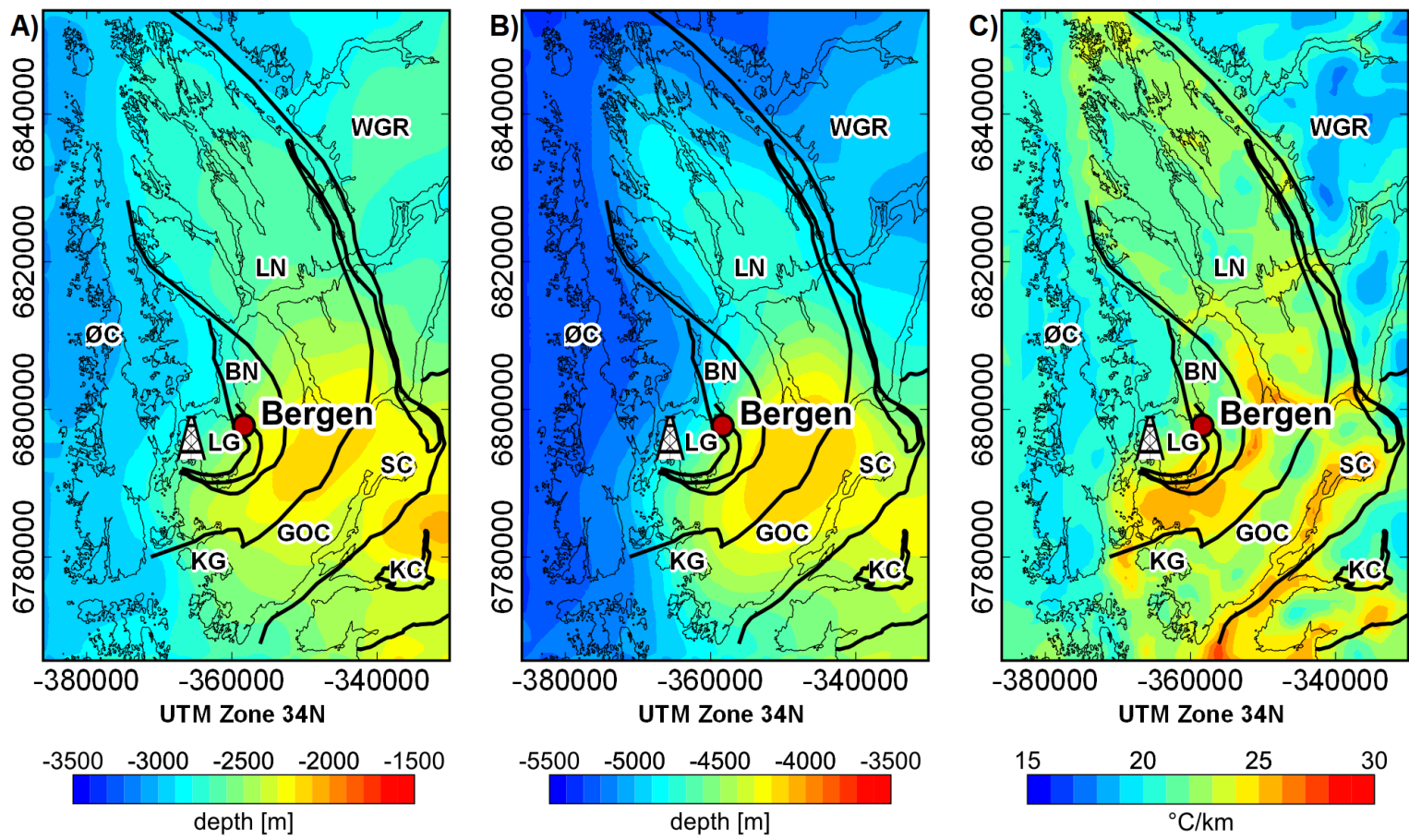

Figure 11. Illustration of the deep geothermal potential in the Bergen Arc System: (A) depth of the $60^{\circ} \mathrm{C}$ isotherm, (B) depth of the $100^{\circ} \mathrm{C}$ isotherm, and (C) spatial distribution of the vertical temperature gradient. BN-Blåmanen Nappe, GOC-Gullfjellet Ophiolite Complex, KC - Kikedal Complex, KG - Krossnes Granite, LG - Løvstakken Granite, LN - Lindås Nappe, ØC- Øygarden Complex, SC-Samnanger Complex, WGR - Western Gneiss Region.

\section{Discussion}

\section{Structure of the Løvstakken Granite}

We developed three plausible 3D models for the Bergen Arc System that describe the magnetic and gravitational anomalies equally well (see Figs. $7 \&$ 8). The challenge in modelling the basement structure in this region is the relative low density contrast between the Løvstakken Granite and the surrounding gneiss of the $\varnothing$ ygarden Complex and WGR, which produces only a small gravity anomaly. Furthermore, these anomalies are partly superimposed by the gravitational effects of overlying Caledonian Nappes. However, the additional use of magnetic data has helped to separate the different sources.

Whether the Løvstakken Granite is structurally and compositionally connected to the Kikedal Complex remains uncertain. The differentiation of the two horizons is most likely possible on the basis of their magnetic properties because the petrophysical analysis revealed much lower susceptibilities in the Kikedal Complex than in the Løvstakken Granite. This observation is further supported by the measured magnetic anomalies. Conversely, it has also been shown that the susceptibility can vary widely within individual bodies. More precise statements about the structure of the Løvstakken Granite can, therefore, only be made based on further geological, geophysical or geochemical investigations. 


\section{Factors influencing the subsurface temperatures}

We investigated the influence of four different factors on the subsurface temperatures in the Bergen Arc System. A comparison of the temperature log from the Fyllingsdalen borehole with the predicted temperatures showed that the radiogenic heat production has the strongest effect of all parameters. We found that the estimates of the heat production based on the surface rock analysis (see Table 1) are not a good representation of the whole crust. Instead, the concentration of radioactive elements is on average $\sim 50 \%$ lower in the basement than at the surface which corresponds to a mean heat production of $1.5 \mu \mathrm{W} / \mathrm{m}^{3}$. A detailed evaluation of the heat production measured in existing deep continental drillings, such as the KTB or the Kola Superdeep Borehole, could be helpful to find a more accurate estimate of this parameter.

Furthermore, the influence of the structure of the $L \varnothing v s t a k k e n$ Granite was quantified by comparing the predicted temperatures for the three geological models A, B and C (see Figs. 7 \& 8). The differences in the determined geothermal gradient are about $3^{\circ} \mathrm{C} / \mathrm{km}$ and especially for the small granite in Model $\mathrm{C}$ we calculated significantly lower subsurface temperatures. Nevertheless, in this region, the geological structure seems to be of secondary importance compared with the effect of different heat production rates.

The vertical temperature gradient was also strongly affected by the last glaciations in western Norway. For this reason, a correction of the modelling results was carried out using a paleotemperature reconstruction after Olsen (2006) and Maystrenko et al. (2015b) (see Fig. 5). This time series is based on simplifying assumptions about the paleoclimatic conditions in the Bergen Region and hence subject to great uncertainties $\left( \pm 8^{\circ} \mathrm{C}\right)$. Moreover, it should be noted that the correction was done for only the past 220 ka because there is no reliable information for earlier times. However, surface temperatures varied strongly throughout the whole of the Pleistocene (e.g., Emiliani, 1955). It can, therefore, be summarised that an improved reconstruction of the paleotemperatures would also result in a more adequate correction.

In addition, there was clear evidence of substantial groundwater flow through the Løvstakken Granite in the Fyllingsdalen borehole. Based on these observations, Elvebakk \& Storrø (2013) concluded that the fluid flow would considerably reduce the thermal gradient at the drill site. We developed a coupled 2D groundwater and heat transport model to test this hypothesis. Since the hydrological data were insufficient, simplifying assumptions about the boundary conditions and hydraulic properties were made. Above all, the modelled groundwater flow is affected by the permeability, hence the definition of this parameter is particularly critical. We made use of the empirical permeability law after Shmonov et al. (2003) which leads to moderate changes in the subsurface temperatures due to advection of $\pm 5^{\circ} \mathrm{C}$. However, a significant change was not identified at the Fyllingsdalen borehole. Similar depthpermeability relationships were found by Strober \& Bucher (2007) and Manning \& Ingebritsen (1999) that might lead to different modelling results. In general, the geological horizons of the Bergen Arc System are most likely so-called joint aquifers, which means that the groundwater flow is mainly controlled by the size and frequency of permeable fracture zones. This depends, inter alia, on the composition, structure, stress state and tectonic history of the individual tectonic unit. For this reason, the use of a general permeability law for the whole model should be viewed critically.

In contrast to Maystrenko et al. (2015a), we did not find a regional, but rather a local groundwater flow pattern restricted to the upper 1 to $2 \mathrm{~km}$ of the crust. This might again be due to varying definitions of the permeability in the two models. Another reason for these different observations could be that we did not include the adjacent northern North Sea in our model which probably influences the terrestrial subsurface fluid flow. In summary, additional field and laboratory measurements on hydraulic 
properties would improve the results and coupled groundwater and heat transport modelling should also be performed in 3D for more accurate results in future studies.

Apart from the investigated processes, several further aspects might influence subsurface temperature distribution. Besides the paleoclimate effect described above, which is based on conduction, the last glaciations most likely also affected the advective heat transport in the upper crust. In particular, the basal flow of meltwater resulted in a cooling of the subsurface, but the magnitude of the temperature reduction is not clear at present. Moreover, the postglacial uplift led to massive erosion in the Quaternary which might have caused an increase in the geothermal gradient. However, we assume that these effects are relatively small, but we did not carry out a full sensitivity analysis, which is beyond the current study, where the emphasis is on the structure of the Løvstakken Granite.

\section{Geothermal potential}

We carried out an assessment of the deep geothermal potential in the Bergen Arc System based on the predicted subsurface temperatures. The advantage of the developed 3D model is that the entire Bergen Region was considered and not just a $2 \mathrm{D}$ line. A medium potential was determined for the extraction of heating energy and a possible drilling location could be the urban area of Bergen because of the increased thermal gradient there. The potential for producing electricity is in comparison rather low. However, it should be noted that the petrothermal potential is, in addition to the temperatures, affected by several parameters such as thermal conductivity, heat capacity, permeability or tectonic stresses. In order to perform a detailed quantification of the energy quantities that can be exploited, these factors must also be considered.

Moreover, the groundwater effect might be underestimated as mentioned before. This is particularly the case if there is a regional groundwater flow as simulated by Maystrenko et al. (2015a). Consequently, the effect of advective heat transport on the deep geothermal potential might be stronger than determined in this study. As shown in Fig. 10, the local groundwater flow can lead to a lowering but also to an increase of the subsurface temperatures, which makes the assessment of the influence even more complicated.

Apart from the extraction of the inherent thermal energy in the crust, also the installation of a seasonal heat storage is possible in the Bergen Arcs. Especially schools, supermarkets, hospitals, etc. produce large amounts of excess heat in summer which could be transferred to the crystalline basement on a large scale. The thermal properties of the overlying thrust sheets would thereby allow for effective storage of the energy. In winter, the heat could be extracted again and be fed into the district heating network.

\section{Conclusions}

We developed three plausible 3D models of the Bergen Arc System by integrating geological and geophysical data. The emphasis was on the structure of the Løvstakken Granite which could possibly serve as the source rock for deep geothermal energy. Predictions of the subsurface temperatures were conducted and the results were compared with the measurements in the Fyllingsdalen borehole. Based on these investigations, the following conclusions can be drawn: 
1. The near-surface part of the model is in good agreement with the geological cross-sections of the area. At greater depth, structural constraints are not available, hence the geometry and properties of the Løvstakken Granite and the other basement units are subject to major uncertainties

2. Depending on the geological model, the predicted vertical temperature gradient varies by about $3^{\circ} \mathrm{C} / \mathrm{km}$.

3. The radiogenic heat production in the crust is a key factor in terms of subsurface temperatures. The comparison of the calculated temperatures with the measurements in the Fyllingsdalen borehole showed that the heat production is on average $\sim 50 \%$ smaller in the entire basement than at the surface in the Bergen Arcs which corresponds to a mean heat production of $1.5 \mu \mathrm{W} / \mathrm{m}^{3}$.

4. The paleoclimate conditions of the Pleistocene are still significantly affecting the vertical temperature gradient in the study area. Therefore, we performed a correction of the modelling results regarding the paleotemperatures in western Norway.

5. As presumed, the subsurface temperature distribution in the Bergen Region is partly affected by groundwater flow, but a significant reduction of the thermal gradient due to the groundwater was not simulated at the Fyllingsdalen borehole. However, due to the sparse data on hydraulic properties, the uncertainties remain high.

6. We assessed that there is an intermediate potential for the extraction of hot water for a district heating network in the city of Bergen. For the generation of electricity with a deep geothermal drilling, there is only a small potential. However, an exact quantification of the geothermal potential is not possible at present because, on the one hand, the groundwater influence has not yet been conclusively determined and, on the other hand, the reservoir properties are still subject to great uncertainties.

Acknowledgements. We thank the editor Trond Slagstad and reviewer Yuriy Maystrenko for their constructive remarks, which helped us to improve the manuscript. We also thank all scientists and sponsors of the 'Crustal Onshore-Offshore Project' (COOP) which was the essential basis for our study. We are particularly grateful to Odleiv Olesen for the good cooperation in the project, Yuriy Maystrenko for making the regional 3D IGMAS model of western Norway and the North Sea area available, and Aziz Nasuti for providing the magnetic data of the Bergen region. Special thanks go to Dirk Schäfer for his support in developing the groundwater model.

\section{References}

Amante, C. \& Eakins, B.W. 2009: ETOPO1 Global Relief Model converted to PanMap layer format. National Oceanic and Atmospheric Administration Technical Memorandum NESDIS NGDC-24, 1-19.

Austrheim, H. 1987: Eclogitization of lower crustal granulites by fluid migration through shear zones. Earth and Planetary Science Letters 81, 221-232. https://doi.org/10.1016/0012-821X(87)90158-0.

Austrheim, H. 1990: The granulite-eclogite facies transition: A comparison of experimental work and a natural occurrence in the Bergen Arcs, western Norway. Lithos 25, 163-169.

https://doi.org/10.1016/0024-4937(90)90012-P. 
Austrheim, H. \& Griffin, W.L. 1985: Shear deformation and eclogite formation within granulitefacies anorthosites of the Bergen Arcs, western Norway. Chemical Geology 50, 267-281. https://doi.org/10.1016/0009-2541(85)90124-X.

Bauer, M, Freeden, W, Jacobi, H \& Neu, T. 2014: Handbuch Tiefe Geothermie. Springer-Verlag, Berlin, Heidelberg, 854 pp. https://doi.org/10.1007/978-3-642-54511-5.

Beardsmore, G.R. \& Cull, J.P. 2001: Crustal Heat Flow. A Guide to Measurement and Modelling. Cambridge University Press, 336 pp. https://doi.org/10.1017/СBO9780511606021.

Čermak, V. \& Rybach, L. 1982: Thermal properties: Thermal conductivity and specific heat of minerals and rocks. In Angenheister, G. (ed.): New Series, Geophysics and space research, Springer, Berlin, pp. 303-343.

Clauser, C. 2003: Numerical Simulation of Reactive Flow in Hot Aquifers. Springer, Berlin, Heidelberg, 348 pp. https://doi.org/10.1007/978-3-642-55684-5.

Corfu, F., Andersen, T.B. \& Gasser, D. 2014: The Scandinavian Caledonides: main features, conceptual advances and critical questions. Geological Society, London, Special Publications 390, 9-43. https://doi.org/10.1144/SP390.25.

Dunning, G.R. \& Pedersen, R.B. 1988: U/Pb ages of ophiolites and arc-related plutons of the Norwegian Caledonides: implications for the development of lapetus. Contributions to Miner-alogy and Petrology 98, 13-23. https://doi.org/10.1007/BF00371904.

Elvebakk, H. \& Storrø, G. 2013: Logging of the Fyllingsdalen, Alstein and Ullrig boreholes. In Olesen, O., Brönner, M., Ebbing, J., Elvebakk, H., Gellein, J., Koziel, J., Lauritsen, T., Lutro, O., Maystrenko, Y., Müller, C., Nasuti, A., Osmundsen P.T., Slagstadt, T. \& Storrø, G. (eds.): Coop Phase I - Crustal Onshore-Offshore Project. NGU Report 2013.002, 44-62 pp.

Emiliani, C. 1955: Pleistocene Temperatures. The Journal of Geology 63, 538-578. https://doi.org/10.1086/626295.

EON Geosciences. 2013: Fixed Wing Stavanger-Trondheim Aeromagnetic Survey 2013 (STAS-13). Final Survey Report, $36 \mathrm{pp}$.

Fossen, H. 1988: The Ulriken Gneiss Complex and the Rundemanen Formation: a base-ment-cover relationship in the Bergen Arcs, West Norway. Norges Geologiske Undersøkelse Bulletin 412, 67-88.

Fossen, H. 1989: Geology of the Minor Bergen Arc, West Norway. Norges Geologiske Unders $\varnothing$ kelse Bulletin 416, 47-62.

Fossen, H. 1992: The role of extensional tectonics in the Caledonides of south Norway. Journal of Structural Geology 14, 1033-1046. https://doi.org/10.1016/0191-8141(92)90034-T.

Fossen, H. 1993: Structural evolution of the Bergsdalen Nappes, Southwest Norway. Norges Geologiske Undersøkelse Bulletin 424, 23-49.

Fossen, H. 1998: Advances in understanding the post-Caledonian structural evolution of the Bergen area, West Norway. Norwegian Journal of Geology 78, 33-46. 
Fossen, H. \& Austrheim, H. 1988: Age of the Krossnes Granite, West Norway. Norges Geologiske Undersøkelse Bulletin 413, 61-65.

Fossen, H. \& Dunlap, W.J. 2006: Age constraints on the late Caledonian (Scandian) deformation in the Major Bergen Arc, SW Norway. Norwegian Journal of Geology 86, 59-70.

Fossen, H., Dunlap, W.J., Steltenpohl, M.G., Carter, B.T., Andresen, A. \& Zeltner, D.L. 1998: Timing and kinematics of Caledonian thrusting and extensional collapse, southern Norway: evidence from 40Ar/39Ar thermochronology. Journal of Structural Geology 20, 765-781.

https://doi.org/10.1016/S0191-8141(98)00007-8.

Fossen, H. \& Ingdahl, S.E. 1987: Tectonostratigraphic position of the rocks in the western extreme of the Major Bergen Arc (Fanafjell Nappe), West Norway. Norwegian Journal of Geology 67, 59-66.

Fossen, H. \& Rykkelid, E. 1990: Shear zone structures in the Øygarden area, West Norway. Tectonophysics 174, 385-397. https://doi.org/10.1016/0040-1951(90)90333-4.

Fugro, 2010: Fixed Wing Airborne Magnetic and Radiometric Survey over the Bergen-Stavanger Region (BESTAS-10). Geological Survey of Norway Processing Report, Project FCR2516.

Gee, D. \& Sturt, B. 1985: The Caledonide Orogen - Scandinavia and related areas. John Wiley \& Sons, Chichester, 1266 pp.

Gee, D.G., Fossen, H., Henriksen, N. \& Higgins, A.K. 2008: From the Early Paleozoic Plat-forms of Baltica and Laurentia to the Caledonide Orogen of Scandinavia and Greenland. Episodes 31, 44-51. https://doi.org/10.18814/epiiugs/2008/v31i1/007.

Gibson, H., Stüwe, K., Seikel, R., FitzGerald, D., Calcagno, P., Guillen, A. \& Mclnerney, P. 2008: Forward prediction of temperature distribution direct from 3D geology models. Proceedings of the 2008 Australian Geothermal Energy Conference, 19-22 August, Melbourne, p. 8.

Glodny, J., Kühn, A. \& Austrheim, H. 2008: Geochronology of fluid-induced eclogite and amphibolite facies metamorphic reactions in a subduction-collision system, Bergen Arcs, Nor-way. Contributions to Mineralogy and Petrology 156, 27-48. https://doi.org/10.1007/s00410-007-0272-y.

Götze, H.J. 2013: Potential Methods and Geoinformation Systems. In Freeden, W., Nashed, M. \& Sonar, T. (eds.): Handbook of Geomathematics, Springer, Berlin, Heidelberg, pp. 2-21. https://doi.org/10.1007/978-3-642-27793-1_52-2.

Götze, H.J. \& Lahmeyer, B. 1988: Application of three-dimensional interactive modeling in gravity and magnetics. Geophysics 53, 1096-1108. https://doi.org/10.1190/1.1442546.

Guillen, A., Courrioux, G., Calcagno, P., Lane, R., Lees, T. \& Mclnerney, P. 2004: Con-strained gravity 3D litho-inversion applied to Broken Hill. Australian Society of Exploration Geophysicists Extended Abstracts, 6 pp. https://doi.org/10.1071/ASEG2004ab057.

Hermansen, E. 2019: Mapping of fracture corridors in the basement rocks of the Øygarden Complex, Western Norway. MSc Thesis, University of Bergen, 72 pp. 
Heskestad, B., Hofshagen, N.H., Furnes, H. \& Pedersen, R.-B. 1994: The geochemical evo-lution of the Gulfjellet Ophiolite Complex, west Norwegian Caledonides. Norwegian Journal of Geology 74, 77-88. Intrepid Geophysics. 2013: GeoModeller User Manual. www.intrepid-geophys-ics.com/ig/uploads/ manuals/documentation_pdf_geomodeller/pdf_en/GeoModeller_Reference.pdf (09.01.2019).

Jones, A.G., Plomerova, J., Korja, T., Sodoudi, F. \& Spakman, W. 2010: Europe from the bottom up: A statistical examination of the central and northern European lithosphere-asthenosphere boundary from comparing seismological and electromagnetic observations. Lithos 120, 14-29. https://doi.org/10.1016/j.lithos.2010.07.013.

Kolderup, C.F. \& Kolderup, N.-H. 1940: Geology of the Bergen Arc System. A.S John Grieg Boktrykkeri, $137 \mathrm{pp}$.

Kühn, A., Glodny, J., Austrheim, H. \& Råheim, A. 2002: The Caledonian tectono-metamorphic evolution of the Lindås Nappe: Constraints from U-Pb, Sm-Nd and Rb-Srages of granitoid dykes. Norwegian Journal of Geology 82, 45-57.

Manning, C.E. \& Ingebritsen, S.E. 1999: Permeability of the continental crust: Implications of geothermal data and metamorphic systems. Reviews of Geophysics 37, 127-150. https://doi.org/10.1029/1998RG900002.

Maystrenko, Y., Elvebakk, H. \& Kurtic, J. 2013: 2D crustal and thermal modelling within the Bergen and Stavanger areas. In Olesen, O., Brönner, M., Ebbing, J., Elvebakk, H., Gellein, J., Koziel, J., Lauritsen, T., Lutro, O., Maystrenko, Y., Müller, C., Nasuti, A., Osmundsen P.T., Slagstadt, T. \& Storrø, G. (eds.): Coop Phase I - Crustal Onshore-Offshore Project. NGU Report 2013.002, 197-257 pp.

Maystrenko, Y., Olesen, O., Ebbing, J. \& Nasuti, A. 2017: Deep structure of the northern North Sea and south-western Norway based on 3D density and magnetic modelling. Norwegian Journal of Geology 97, 169-210. https://doi.org/10.17850/njg97-3-01.

Maystrenko, Y., Olesen, O. \& K. Elvebakk, H. 2015a: Indication of deep groundwater flow through the crystalline rocks of southern Norway. Geology 43, 327-330. https://doi.org/10.1130/G36318.1.

Maystrenko, Y.P., Slagstad, T., Elvebakk, H.K., Olesen, O., Ganerød, G.V. \& Rønning, J.S. 2015b: New heat flow data from three boreholes near Bergen, Stavanger and Moss, southern Norway. Geothermics 56, 79-92. https://doi.org/10.1016/j.geothermics.2015.03.010.

McKerrow, W.S., Mac Niocaill, C. \& Dewey, J.F. 2000: The Caledonian Orogeny redefined. Journal of the Geological Society 157, 1149-1154. https://doi.org/10.1144/jgs.157.6.1149.

Middlemost, E.A.K. 1970: Anorthosites: A graduated series. Earth-Science Reviews 6, 257-265. https://doi.org/10.1016/0012-8252(70)90080-2.

Nasuti, A., Olesen, O., Baranwal, O. \& Dumais, M.-A. 2015: Compilation of aeromagnetic data. In Olesen, O., Baranwal, O., Brönner, M., Dalsegg, E., Dumais, M.-A., Gellein, J., Ger-nigon, L., Heldal, T., Larsen, B.E., Lauritsen, T., Lutro, O., Maystrenko, Y., Nasuti, A., Rob-erts, D., Rueslåtten, H., Rønning, J.S., Slagstad, T., Solli, A. \& Stampolidis, A. (eds.): Coop Phase 2 - Crustal Onshore-Offshore Project. NGU confidential Report 2015.063, 11-24 pp. 
Olesen, O. \& Brönner, M., Ebbing, J., Gellein, J., Gernigon, L., Koziel, J., Lauritsen, T., Myklebust, R., Pascal, C., Sand, M., Solheim, D. \& Usov, S. 2010: New aeromagnetic and gravity compilations from Norway and adjacent areas - methods and applications. Petroleum Geology Conference series 7, 559-586. https://doi.org/10.1144/0070559.

Olesen, O., Brönner, M., Ebbing, J., Elvebakk, H., Gellein, J., Koziel, J., Lauritsen, T., Lutro, O., Maystrenko, Y., Müller, C., Nasuti, A., Osmundsen P.T., Slagstadt, T. \& Storr $\varnothing$, G. 2013: Coop Phase I - Crustal Onshore-Offshore Project. NGU Report 2013.002, 359 pp.

Olesen, O., Reitan, M. \& Sæther, P.O. 1993: Petrofysisk database PETBASE 3.0, Brukerbe-skrivelse. NGU Report 93.023.

Olsen, L. 2006: Fennoscandia M-L Weichselian glacial variations - much more than just local icemargin fluctuations. In Peltonen, P. \& Pasanen, A. (eds): The 27th Nordic Geological Win-termeeting, Bulletin of the Geological Society of Finland, Special Issue.

Pascal, C. \& Rudlang, T. 2016: Discovery of highly radioactive granite in the Bergen Region. Norwegian Journal of Geology 96, 319-328. https://doi.org/10.17850/njg96-4-03.

Pattyn, F. 2010: Antarctic subglacial conditions inferred from a hybrid ice sheet/ice stream model. Earth and Planetary Science Letters 295, 451-461. https://doi.org/10.1016/j.epsl.2010.04.025.

Ragnhildstveit, J. \& Helliksen, D. 1997: Geological map of Norway, bedrock map Bergen, scale 1:250,000, Norges geologiske unders $\varnothing$ kelse.

Reusch, H.H. 1882: Silurfossiler og pressede konglomerater i Bergensskifrene. AW Brøg-gers bogtrykkeri, 168 pp.

Rybach, L. 1988: Determination of heat production rate. In Hänel R, Rybach, L. \& Stegena, L. (eds.): Handbook of Terrestrial Heat-Flow Determination, Dordrecht: Kluwer Academic Publishers, pp. $125-142$.

Shmonov, V.M., Vitiovtova, V.M., Zharikov, A.V. \& Grafchikov, A.A. 2003: Permeability of the continental crust: implications of experimental data. Journal of Geochemical Exploration 78-79, 697-699. https://doi.org/10.1016/S0375-6742(03)00129-8.

Sigfússon, B. \& Uihlein, A. 2015: 2014 JRC Geothermal Energy Status Report. Report of the Joint Research Centre of the European Commission, 55 pp.

Slagstad, T., Balling, N., Elvebakk, H., Midttømme, K., Olesen, O., Olsen, L. \& Pascal, C. 2009: Heat-flow measurements in Late Palaeoproterozoic to Permian geological provinces in south and central Norway and a new heat-flow map of Fennoscandia and the Norwegian-Greenland Sea. Tectonophysics 473, 341-361. https://doi.org/10.1016/j.tecto.2009.03.007.

Slagstad, T. \& Lauritsen, T. 2013: Heat production calculations. In Olesen, O., Brönner, M., Ebbing, J., Elvebakk, H., Gellein, J., Koziel, J., Lauritsen, T., Lutro, O., Maystrenko, Y., Mül-ler, C., Nasuti, A., Osmundsen P.T., Slagstadt, T. \& Storrø, G. (eds.): Coop Phase I - Crustal Onshore-Offshore Project. NGU Report 2013.002, 74-88 pp.

Strober, I. \& Bucher, K. 2007: Hydraulic properties of the crystalline basement. Hydrogeology Journal 5, 213-224. https://doi.org/10.1007/s10040-006-0094-4. 
Sturt, B., Skarpenes, O., Ohamian, A.T. \& Pringle, I.E. 1975: Reconnaissance Rb/Sr isochron study in the Bergen Are System and regional implications. Nature 253, 595-599. https://doi.org/10.1038/253595a0. Sylvester, A.G. \& Janecky, D.R. 1988: Structure and petrofabrics of quartzite and elongate pebbles at Sandviksfjellet, Bergen, Norway. Norwegian Journal of Geology 68, 31-50.

Torsvik, T.H. \& Olesen, O. 1988: Petrophysics and Palaeomagnetism. Initial Report of the Norwegian Geological Survey Laboratory. NGU Report 88.171, 108 pp.

Turcotte, D.L. \& Schubert, G. 2002: Geodynamics, 2nd ed. Cambridge University Press, 456 pp. https://doi.org/10.1017/СВ09780511807442.

Tveito, O.E., Førland, E., Heino, R., Hanssen-Bauer, I., Alexandersson, H., Dahlström, B. \& Drebs, A. 2000: Nordic temperature maps. DNMI-Report 09/00 KLIMA, 54 pp.

Wennberg, O., Geoffrey Milnes, A. \& Winsvold, I. 1998: The northern Bergen Are Shear Zone - an oblique-lateral ramp In the Devonian extensional detachment system of western Norway. Norwegian Journal of Geology 78, 169-184.

Wennberg, O.P. 1996: Superimposed fabrics due to reversal of shear sense: an example from the Bergen Arc shear zone, western Norway. Journal of Structural Geology 18, 871-889.

https://doi.org/10.1016/0191-8141(96)00014-4.

Westaway, R. \& Younger, P.L. 2013: Accounting for palaeoclimate and topography: A rigorous approach to correction of the British geothermal dataset. Geothermics 48, 31-51. https://doi.org/10.1016/j.geothermics.2013.03.009. 